IRSH 48 (2003), pp. 36I-399 DOI: I0.10I7/So02085900300I I 23

(C) 2003 Internationaal Instituut voor Sociale Geschiedenis

\title{
Social Engineering and the Contradictions of Modernization in Khuzestan's Company Towns: A Look at Abadan and Masjed-Soleyman*
}

\author{
K A VEH EHSANI
}

Summary: After the discovery of oil in Masjed-Soleyman by employees of the D’Arcy Concession in 1908, the Anglo Persian Oil Company (APOC) was incorporated in London. The oil cities of Abadan, Masjed-Soleyman, and at least seven other sister towns designed and constructed by the APOC in the first quarter of the twentieth century in Khuzestan, were the first modern and industrial towns in Iran and the Middle East. This essay studies Abadan and Masjed-Soleyman company towns with, on the one hand, a modern and authoritarian structure and organization, and on the other hand, thanks to the heterogeneity and energy of their population, as well as the forbidding scale the cities had reached despite the company's wishes, a conditional modernity. The result of these contradictions were cities and urban cultures that were energetic and dynamic, but also eclectic and hybrid.

This essay is a comparative study of the design and social impact of Abadan and Masjed-Soleyman, the first and most important oil towns built in Khuzestan by the Anglo-Persian Oil Company (APOC). The construction of these company towns almost a century ago forms an important chapter in the history of modernization and urbanization in Iran. As a result of this experience, a new model of social engineering and hierarchic modernization was introduced into Iranian social life by powerful actors that included transnational capital, the central state, and professional elites.

Company town, a term coined in the United States at the turn of the century, where this urban form proliferated more than elsewhere, refers to a town owned, designed, maintained, and managed by a single company -

\footnotetext{
* Earlier versions of this paper were presented at a meeting of the Middle East Studies Association, Chicago, 1998, and at the conference on "Twentieth-Century Iran: History From Below", at the International Institute for Social History, Amsterdam, in 200I. A written version in Persian was first published in Goft-o-Gu Quarterly, 25 (1999), pp. 9-46. I would like to thank Touraj Atabaki, Norma Moruzzi, Setenyi Shami, Morad Saghafi, Ahmad Maydari and Kaveh Bayat for their intellectual influence, comments, and friendship.
} 
state owned or private. ${ }^{\mathrm{I}}$ This distinction by exclusive ownership is meant to set company towns apart from other industrial or mining urban areas. Despite the predominance of a major industry, industrial cities such as Detroit or Manchester could not exactly be labeled company towns because the presence of a number of competing employer firms undermined the ability of any one of them to impose its singular will on the urban space in the way that monopoly ownership permits the unique proprietor of a company town, such as Pullman, Illinois or Lakewood, California. ${ }^{2}$

Of the two major aims pursued in the course of the establishment of company towns the first, which is concerned with housing the labor force, is transparent and self-evident. But the second, which is to use the carefully designed urban space for training, monitoring, controlling, and, in short, socializing this labor force according to the demands of the company, is less explicitly attended to. ${ }^{3}$ In Iran the history of modern urbanization has been inextricably tied to the activities of the Anglo-Persian Oil Company (APOC). The oil cities of Abadan, Masjed-Soleyman, and at least seven other sister towns ${ }^{4}$ designed and constructed by the APOC in the first quarter of the twentieth century in Khuzestan were the first modern and industrial towns in Iran and the Middle East. Over time, these cities came to occupy a special place as a model and inspiration for this type of urbanization in the country as other large industrial conglomerates (mostly state-owned) replicated this segregated and hierarchic urban design in the company towns they built - a practice that continues to this day.'

The present essay discusses the history and experience of the oil company towns of Khuzestan, focusing on Masjed-Soleyman and Abadan, the first, largest, and most complex of these cities. Aside from the inherent fascination of looking closely at this formative experience, this study can also allow us to pose several other related concerns, the importance of which may well transcend the mere study of a historical urban form in Iran.

I. John Garner, The Model Company Town (Amherst, MA, I984), pp. 6-7.

2. Lakewood, California is a special case as it was originally an area of orange groves, taken over by the aeronautics industry and converted into a company town suburb for McDonald Douglas, and eventually incorporated into the Greater Los Angeles Metropolis in 1954. See Joan Didion, "Trouble in Lakewood", The New Yorker (26 July i993), pp. 46-65.

3. While it is true that the "paternalism" of classic company towns, such as Pullman, came under criticism even at the time, the alternative social-welfare models that replaced the rigid paternalist company control have tended to be presented as rational and benign in the more official literature.

4. Including the towns of Omidieh, Aqa Jari, Haftkel, Naft-e Sefid, Gachsaran, Lali, and Naft Shahr.

5. Many large public industries and institutions continue to build company towns where their employees reside. These include the railroads, petrochemicals, ports (Mahshahr), fisheries, aluminum, copper mines (Sarcheshmeh), machine tools (Arak), agribusinesses (Dezful, HaftTappeh, Shirin Shahr), steel (Mobarakeh), etc. 
First, if it is true, as I claimed earlier, that some of the main features and practices of this type of urban design have become "nativized" over time and tend to be utilized and referred to on a routine basis, then we must conclude that the important changes that have taken place in the political sphere in the course of this past century have not seriously affected the norms, outlooks, and approaches to development and modernization. It goes without saying that this experience has not been unique to Khuzestan and Iran, since most post-colonial states have tended to adopt models and institutions of the previous era, legitimated by being labeled "national", and subsequently used as instruments of governance and rule by the new state. ${ }^{6}$ In addition, this reference to the colonial period is also repeated on numerous occasions in the process of planning new developmental policies, which use similar methods, approaches, and even criteria. ${ }^{7}$ What

6. Of course, Iran was never a formal colony. However, as I will attempt to demonstrate in the course of this essay, I believe my use of a number of insightful theoretical contributions of postcolonial theory are justified in the light of the near hegemonic control that Britain had over southern Iran, especially in the first quarter of the twentieth century, and the subsequent influence of the discursive and institutional practices of the Anglo-Persian Oil Company (APOC, renamed the Anglo-Iranian Oil Company (AIOC) in I935, and British Petroleum (BP) after 1954) on the technical and bureaucratic elite of Iran, at the provincial and even national levels.

7. Will Swearingen's analysis of Moroccan agriculture, first under French Protectorate and later under national state direction, shows this continuity in convincing detail. See Will Swearingen, Moroccan Mirages: Agrarian Dreams and Deceptions, 19I2-1986 (Princeton, NJ, 1987). The independent postcolonial state basically adopts the institutional, ideological, and practical approaches of the colonial government with regard to its relation to the peasantry, landed elites, forms of property and property relations, and the adoption of appropriate technology. The strength of Swearingen's historical-geographic analysis lies in his acknowledging the importance of the political shift of power to a national state, while analyzing the important continuities. A national state elite derives its legitimacy and survival from a very different set of parameters and priorities than a colonial elite, being primarily responsive to the demands and expectations of its domestic population, rather than the metropole's. Nevertheless, there is a marked continuity in how "development" is conceptualized, a fact that has as much to do with the rise and formation of modern professional elites as with the formation and integration of a national economy into a global capitalist system. Janet Abu-Lughod's classic study of the process of urbanization in precolonial, colonial, and postcolonial Morocco complements Swearingen's, while it is also more detailed and insightful about the material and political constraints facing the postindependence state. See Janet Abu-Lughod, Rabat: Urban Apartheid in Morocco (Princeton, NJ, 1980).

Frederick Cooper throws light on this continuity by taking the historian's approach to the concept of "development" itself. The "development" concept posited that anyone, African subjects included, could formulate and implement economic improvement and growth, given the right institutional structures and proper education. As such, it gradually replaced the racially based ideologies that served to legitimize European rule and supremacy. Initially formulated as a strategy to save the British and French African colonies by making them both more productive as well as less restive and costly, the universalist concept of "development" eventually served as an argument to let go of the colonies, while at the same time it was adopted as a progressive and necessary strategy by nationalist elites. See Frederick Cooper, "Modernizing Bureaucrats, Backward Africans, and the Development Concept", in Frederick Cooper and Randall Packard (eds), International Development and the Social Sciences (Berkeley, CA, I997), pp. 64-92. 
can be deducted from this experience is that even profound changes in the political sphere do not automatically bring the subjectivity and the outlook that shapes social engineering to critical questioning. ${ }^{8}$ The root of this subjectivity cannot be discovered in the political sphere alone, but rather in the more opaque and impersonal layers of the technocracy and bureaucracy that together form the state machinery, and in the Weltanschaunng of educated and professional elites. 9

Second, the continuity of the relevance of these models of social

8. "Social engineering" was a term much in vogue in the pre-First-World-War era of scientific management, industrial welfare, and the liberal state. See Margaret Crawford, Building the Workingman's Paradise (New York [etc.], 1995), ch. 3, pp. 46-60, 48. For further discussion, see the introductory chapter, pp. I-IO.

9. The question of whether the modern professional intelligentsia, composed of technocrats, bureaucrats, and intellectuals, is a "status group", as Max Weber maintained, or is a distinct social class as Konrad and Szelenyi, and Alvin Gouldner (among others) have argued, is a complex and much debated topic that I do not wish to engage here, because I find it to be a theoretical minefield that needs to be approached with care and in some detail. Marxists and "Marxisant" intellectuals have also engaged this question extensively, from Lenin theorizing the role of a professional revolutionary vanguard acting through the party, through Gramsci's theory of an organic intelligentsia forming a historic bloc with other classes to counter the bourgeoisie's hegemony, through the later theories of middling classes, some influenced by historical and empirical experience, others by structuralism. See Max Weber, Economy and Society, 2 vols (Berkeley, CA, I978), vol. 2, pp. 956-1005; George Konrad and Ivan Szelenyi, Intellectuals on the Road to Class Power (New York, I979); idem, "Intellectuals and Domination in PostCommunist Societies", in Pierre Bourdieu and James Coleman (eds), Social Theory for a Changing Society (Boulder, CO, 1991), pp. 337-372; Alvin Gouldner, The Future of Intellectuals and the Rise of the New Class (New York, 1979); Antonio Gramsci, Prison Notebooks (New York, 197I); Harry Braverman, Labor and Monopoly Capital (New York, 1974); David Noble, America by Design (New York, I977); Pat Walker (ed.), Between Labor and Capital (Boston, MA, 1979); James Weinstein, Corporate Ideal in a Liberal State (Boston, MA, I968); Nicos Poulantzas, Political Power and Social Classes (London, I973).

My own argument is rather eclectic. I find sociological value in Gouldner's thesis of the intelligentsia as a unified, albeit heterogeneous group. But I think it is important to base the overall argument for the rise of a professional middle class/intelligentsia in strong historical argument. Such historical evidence will show that since the early era of modern capitalism and nation-state formation there has been an ever more pronounced trend towards the greater professionalization of managerial skills, in the larger sense of overseeing the reproduction of society against various internal threats as well as its advancement (the strive for growth being inherent in competitive capitalism). See Harold Perkin, The Rise of Professional Society: England Since I 880 (New York [etc.], I989). For the profession that primarily concerns our argument here, Benevolo traces the rise of the spatial planning profession, as an activity that strives to modify and correct the nefarious results of modernization and class struggle (between labor and capital, as well as between competing capitalists), to the early nineteenth century. This is the period when "circumstances had crystallized sufficiently not only to cause the discomfort but also to provoke the protest of the people involved". See Leonardo Benevolo, The Origins of Modern Town Planning (Cambridge, MA, I967), p. 32. John Friedmann, Planning in the Public Sphere (Princeton, NJ, 1987), pp. 51-310, presents a range of various approaches planning theory has adopted over the last two centuries. In addition to historical evidence and theoretical arguments for considering the emergence of a professional class, I have also found great value in 
engineering should logically lead to a closer look at their original formation, or the colonial period. Modern colonialism involves the coercive domination of an alien power whose primary aim is the unaccounted extraction of material and human resources of a subjugated society. Although Iran has not been a modern colony at any time, nevertheless the humiliating influence and hegemonic domination of the APOC has always been locally interpreted as a colonial experience. ${ }^{10}$ The control and ownership of oil resources was, from the onset, a national concern for Iran. At every major related historical juncture when negotiations and conflict redrew the balance of power over the possession and control of petroleum resources - from the D'Arcy Concession of I908, to the I9I9 and 1930 agreements, the oil nationalization movement of the I950s, the post-coup-d'état Consortium, the OPEC Cartel formation, and the price hikes of the I970s, and eventually the Islamic Revolution of 1978 - we have been witnessing a greater share of the control and possession of oil resources gradually pass into the hands of the Iranian state. ${ }^{\text {I }}$

Nevertheless, if we were to shift our perspective from the "national" vantage point, i.e. from the point of view of the central state, and look at the institution of the "Oil Company" from the point of view of the local

linking changes in material historical conditions with shifts in "mentalities" and new discourse formations. Paul Rabinow's exploration of the formation of modern social management disciplines and discourses during the Third Republic in France also sheds light on how various forms of scientific theories combine with explicitly political practices and become the means of drastic intervention and social engineering aimed at modernizing populations, be it in colonized Morocco or metropolitan France. See Michel Foucault, Discipline and Punish: the Birth of the Prison (New York, 1977); Paul Rabinow, The French Modern (Boston, MA, I991).

I०. The APOC always maintained that it was a private commercial company, with no explicit political ambitions, although its scale, commercial dealings with the central government, and the shear fact of it being the single largest private and foreign industrial employer in the country inevitably made its presence rather sensitive to the local and national society. This is the general tone of the argument in the official history of the company. See Ronald Ferrier, The History of the British Petroleum Company, vol. I (Cambridge, 1982); J.H. Bamberg, The History of the British Petroleum Company, vol. 2 (Cambridge, 1994). The British government became the majority shareholder of the APOC in I9I4. This was a strategic move, as the fledgling company was facing financial difficulties in its early operations, and the British navy was speeding up its conversion to oil from coal during the war. Despite substantial government ownership, the APOC continued to be run as a private concern. Nevertheless, the claims of its political impartiality are rather far-fetched. For a more balanced view see Mostafa Elm, Oil, Power, and Principle (Syracuse, NY, 1992), and L.P. Elwell-Sutton, Persian Oil: A Study in Power Politics (London, 1955). The strategic importance of oil to Britain and the government's relation to the industry and producing countries can be found in Marian Kent, Oil and Empire (London, 1976), a study dealing primarily with Iraq. See too S.H. Longrigg, Oil in the Middle East: Its Discovery and Development, $3 \mathrm{rd}$ edn (London, 1967); Geoffrey Jones, The State and the Emergence of British Oil Industry (London, I981).

Ir. See Elm, Oil, Power, and Principle, and Elwell-Sutton, Persian Oil: A Study in Power Politics. 
society, i.e. Khuzestan, then it would be legitimate to ask how much in fact the relation of power that has existed between these two over the past century has actually changed over time? For local society in Khuzestan, the powerful institution that controls the petroleum resources of this province may have undergone many metamorphoses, from the AngloPersian to the Anglo-Iranian, to the National Iranian Oil Companies and eventually to the Petroleum Ministry, but it has always remained an awesome, forbidding, mysterious, and secretive presence that has been beyond local reach and control. For local society this institution continues to appear as a mysterious and alien empire that miraculously extracts local resources and riches and transports them elsewhere without benefiting the local society in any way, aside from the wages paid to its employees. The resulting wealth ends up being accumulated in other locations, i.e. in the distant and alien places where decisions about this local society are also made, be they called London or Tehran!

In other words, the relationship of power that has taken shape between the local society and the political system in power, be it a central national state or an occupying foreign power, has not been fundamentally altered despite the significant political changes that have taken place. This relationship of power demands separate and autonomous analysis - if for no other reason than that the relationship between an independent and centralized "national" state and its own internal communities can be as exploitative and "colonialist" as the domination by an alien power. ${ }^{\mathrm{I} 2}$

Third, an analysis of oil towns would inevitably require closer attention to their raison d'être: the oil industry and economy, and their role in both shaping and creating these cities as well as in the larger national trends and events. Some thirty years ago Hossein Mahdavi (I970) published an essay entitled "The Patterns and Problems of Economic Development in Rentier States", which is still referred to as a classic intervention in the field of

I2. My intention here is not to equate the independent national state with the colonial state, but rather to draw attention to both striking continuities and similarities often found in their style of rule and their relation to the population, as well as to the fundamental imbalance of power between the local society and the central power. These imbalances can often take the form of an internal colonial relationship. For a discussion of this concept, see Christian Rogerson, "Internal Colonialism, Transnationalization, and Spatial Inequality", South African Geographical Journal, 62 (1980), pp. I03-I 20; Stephen Williams, "Internal Colonialism, Core Periphery Contrasts and Devolution: An Integrative Comment", Area, 9 (1977), pp. 272-279; John Lovering, "The Theory of the 'Internal Colony' and the Political Economy of Wales", Review of Radical Political Economy, 10:3 (1978), pp. 57-67. Two classic studies of the two oldest modern nationstates use the concept of internal colonialism to describe the forceful integration of Britain and France's rural and ethnic fringe and populations into the national polity. See Michael Hechter, Internal Colonialism: The Celtic Fringe in British National Development, I536-I966 (Berkeley, CA, 1975), and Eugen Weber, Peasants into Frenchmen: The Modernization of Rural France, I870-1914 (Stanford, CA, 1976). 
comparative political economy. In this essay, using David Ricardo's theory of rent, Mahdavi analyzed the impact of oil revenues on the economic as well as the political sectors of Iran and other oil-producing nations. ${ }^{\mathrm{I}}$

Undoubtedly the "rentier-state" theory has played an important role in the clarification and the political economic analysis of oil-producing societies. On the other hand, like any theory, it is in need of further modifications and critical reassessment. ${ }^{\mathrm{I}}$ Here, I will briefly pose two criticisms, which are related to our present topic: first, the relation between state and society is far more complex and involved than the financial interdependence. The primarily functionalist approach of the "rentierstate" theory has difficulty in explaining both exceptions, such as

I3. See Hossein Mahdavi, "The Patterns and Problems of Economic Development in Rentier States", in M.A. Cook (ed.), Studies in the Economic History of the Middle East (London, 1970). The gist of Mahdavi's argument was that the relative financial autonomy these states enjoy from their societies as a result of their oil revenues also translates into a related political autonomy of the state from society. Petroleum products are exported abroad and the subsequent income comes from the world market. The oil industry itself employs but a tiny segment of the labor force, and consequently has negligible linkages of any kind to the other integrated productive sectors of the national economy. Oil revenues, like a rent, are directly transferred from the foreign purchaser into the Treasury, and are then distributed according to the whims and choices of the state.

The relationship of the state to society is fundamentally distorted and uneven as a result of the origins of its financial revenues and the special place they come to occupy within the national economy. According to this theory, the relationship between state and society is "normal" and "natural" only when the source of state income is direct taxation of the citizens' income. State revenue in that case would be generated from the produced wealth of the nation itself, instead of being a "rent" derived without significant productive activity, but from monopoly ownership of a strategic resource. This "normal" relationship obligates the state to be accountable to society and to citizens, as its role is merely the redistribution of wealth resulting from social production. Echoing de Tocqueville, the argument goes on to claim that civil society would democratically impose its own claims upon state expenditures and investments through legislative and political institutions, as they are a share of the collectively produced social wealth.

In contradistinction, in a rentier state, where the state's financial revenues are not organically linked to national productive economy, the state becomes the powerful, authoritarian and paternalist distributor of seemingly windfall revenues without being compelled to account for its decisions to society. Deprived of an important economic aspect of its dialectical relationship to the state, the society becomes fragmented into clientelist interest groups, competing to obtain greater shares of the "rent" distributed by the state. The state, on the other hand, coopts these groups by selectively distributing resources among them, in exchange for their political passivity and support. Rentier states, in other words, are inherently undemocratic, made of a passively apolitical society and an authoritarian state.

I4. Two of the most important re-assessments of both the rentier-state theory as well as oilproducing economies and societies can be found in Kiren Aziz Chaudhry, The Price of Wealth: Economies and Institutions in the Middle East (Ithaca, NY, 1997); and Terry Lynn Karl, The Paradox of Plenty: Oil Booms and Petro-States (Berkeley, CA, 1997). 
democratic Norway, ${ }^{15}$ and the popular democratic reform movement currently taking place in the Islamic Republic of Iran. It would be also difficult to explain why, despite the generous distribution of rent, some passive societies suddenly produce sustained social protest movements, unless such political upheavals are explained away as a sudden fiscal and financial crisis, brought about by either drastic falls in oil revenues or in the pattern of rent distribution by the state. ${ }^{16}$ Neither of these explanations has been convincing in explaining the occurrence of the Iranian Revolution of I979.

But the second criticism I will level at this theory is perhaps more pertinent to the topic at hand. The focus of this theory on the state's sources of revenue has limited its analytical scope to the macro-economy, thus preventing it from taking a more serious empirical look at the role of

I 5. For a discussion of Norway and its social and geographic dealings with its oil industry see Jens Hansen, "Regional Policy in an Oil Economy: The Case of Norway", Geoforum, I4 (1983), pp. 353-36r; and Karl, The Paradox of Plenty: Oil Booms and Petro-States, pp. 21 3-221. Karl argues that the difference in the case of Norway lies in the fact that nation-state formation had taken place prior to the spectacular rise in oil revenues of the late twentieth century.

I6. Giacomo Lucciani probably goes further than most in reducing the possibility of social change in societies ruled by rentier states to the occurrence of a serious financial crisis. Apparently his exclusive focus on Arab states allows him to overlook the uncomfortable example of Iran. The 1979 Revolution did occur simultaneously with high inflation, but this economic crisis could not be taken as the cause, nor as the primary trigger, of the events that toppled the monarchy. The continued economic crisis of oil-producing states has not brought about any political challenges elsewhere in the Middle East, any more than it has in other developing countries in the pattern that John Walton has called "bread riots". See Giacomo Lucciani, “Allocation vs. Production States: A Theoretical Framework", in idem (ed.), The Arab State (Berkeley, CA, I 990), pp. 65-84; and idem, "The Oil Rent, the Fiscal Crisis of the State and Democratization", in Ghassan Salame (ed.), Democracy Without Democrats? The Renewal of Politics in the Muslim World (London, I994), pp. I30-I 55 .

Theda Skocpol, in an attempt to test her comparative theory of social revolutions using the Iranian case, came to the conclusion that it did not quite fit her model. She then used the "rentierstate" theory to explain the dynamic of state and society relation and further claims that "traditional" Shi'a Islam had been able to maintain an autonomous space away from the modernization and the modernity that had otherwise transformed Iranian society. This marginalization and autonomy allowed this traditional Islam to revolt against the rentier state when the time came. Theda Skocpol, Social Revolutions in the Modern World (Cambridge [etc.], I994), pp. $240-258$.

What is common to both these approaches is that the motives leading to popular protest and revolt are not sought within society itself, and all the contradictions and social protests, including political Islam, that capitalist modernization stirs up. Instead, the root causes of social crisis are found in ahistorical or even external factors, such as an "Islam" that has remained unaffected and somehow "pure" in spite of decades of profound social change. Edward Said's work convincingly showed how orientalism tried to locate an unchanging essence in Middle Eastern societies, to explain their deviation from the norm, the norm being the capitalist modernization as experienced in the Western world. See Edward Said, Orientalism (New York, 1979). It seems that many of the proponents of the rentier-state theory have merely "secularized" the orientalist discourse: instead of "Islam" being the key cultural factor explaining the essential unmodernity of the Middle East, an economic factor - oil revenues - is advanced to prove the same point! 
the oil industry itself, and the crucial role it has played in Iran's social history. The claim that, despite its enormous weight in the national political economy, the oil industry has employed only a tiny fraction of the national labor force should not automatically lead to a neglect of the important role that this labor force has played in the social, economic, and political history of labor in Iran. In I95 I, when the oil nationalization movement was taking shape, the Anglo-Iranian Oil Company (AIOC, the renamed APOC) had nearly 80,000 Iranian workers, employees, and contractors on its payroll, ${ }^{17}$ which was a very substantial portion of the national industrial labor force at the time. I do not currently have comparable figures for recent years, but we know that five years later in 1956 - i.e. after the fall of the Mossadeq government following the AngloAmerican coup d'état of 1953, the establishment of the Consortium, and the subsequent downsizing and rationalization of the employment structure of the newly established National Iranian Oil Company (NIOC) - employment in the oil sector had dropped to 25,000, while total national employment in "modern" large industries (defined as those firms employing more than $\mathrm{I} 2$ workers) totaled $60,000 .{ }^{18}$ Employment in the oil sector increased gradually with the rise in production, but as a result of technological improvements and higher efficiency the figures did not exceed 55,000 in 1977, at the time of the Revolution, while employment in large industries during this period experienced a rapid growth, reaching 4I 5,000 people. ${ }^{19}$

Despite the relative decline of the share of oil-sector workers in the total industrial labor force, we can still see that employment in this industry has always accounted for a significant and considerable segment of the modern and skilled working class employed in heavy industries. Our aim here is not to simply stress the numbers, but also to draw attention to the importance of the culture, organizational ability, and experience, and the complex work ethic that the labor force of this modern, well-established, and highly competitive industry had accumulated over a long time. In other words, despite its relative decline in numbers the oil sector continues to be, even today, probably the most advanced and competitive large industry in the country, thanks to its long history and experience.

This maturity and ability is not limited to organizational and productive abilities, but at many junctures has also had political manifestations. In

17. See Ronald Ferrier, "The Iranian Oil Industry", in Peter Avery, Gavin Hambly, and Charles Melville (eds), The Cambridge History of Iran, vol. 7, From Nadir Shab to the Islamic Republic (Cambridge [etc.], 1991), pp. 639-704, 692; Bamberg, The History of the British Petroleum Company, vol. 2; and Fred Halliday, Iran: Dictatorship and Development (London, 1978), p. 177 .

18. Mohammad Sodagar, Roshd-e Ravabet-e Sarmayedari dar Iran (n.p., n.d.), p. 322.

19. Ebrahim Razaqi, Eqtesad-e Iran (Tehran, 1988), p. 384. 
other words, despite the fact that high wages and salaries, as well as relative job security, had turned the oil industry's labor force into something of a labor aristocracy by the 1970 s, ${ }^{20}$ nevertheless this affluence and security did not prevent it from being rapidly attracted to national protests and political goals that transcended its limited guild interests. In 1977-1978 the industrial working class, which occupied a strategic place in the national economy despite its numerically small size, played a paramount role through its mass strikes in the success of the Revolution. Among this class, the workers and employees of the oil industry played the key role by first shutting off the pipelines and suspending all production and exports. After the collapse of the monarchy they succeeded in restarting production and exports without the help of foreign experts, an unprecedented and quite significant event in the Third World. ${ }^{21}$

In his study of the labor syndicates during the Revolution, Assef Bayat points out that what set the workers' committees in the oil industry apart was their sustained autonomy and self-confidence, which allowed them to resist the encroaching "Islamization" that coopted the other labor organizations. This independence led to increasing conflicts with the fledgling provisional government in Tehran. In November 1979, the US embassy was seized in Tehran, just as a new wave of labor, ethnic, and student unrest was escalating. A violent wave of Islamization of educational establishments and workplaces, dubbed the "Cultural Revolution”, was launched in April 1980. In this tempestuous atmosphere, the Iraqi invasion of September 1980 suddenly overshadowed other internal contradictions. More pertinent to our subject here, the Iraqi invasion led to the immediate physical destruction of Abadan and the neighboring port city of Khorramshahr, and the forced dispersal of their populations across the country as refugees. This forced and violent break in the history of these cities leads us to ask the legitimate question whether, if such total destruction had not taken place in a major, strategic industrial city like

20. See Assef Bayat, Workers and Revolution in Iran (London, 1987).

21. This was one of the first instances when the working employees of a developing country succeeded in coordinating independent decisions about running and managing an advanced and strategic global industry. The complex political and psychological impact of this experience comes across in Terisa Turner's "Iranian Oil Workers in the 1978-79 Revolution", and in an oil worker's first-hand account of this historic strike, both in Peter Nore and Terisa Turner (eds), Oil and Class Struggle (London, 1980), pp. 272-302, as well as in Bayat's Workers and Revolution in Iran. However, in the increasingly repressive aftermath of the Revolution, and with the beginning of the Iran-Iraq war, the persecution, emigration, or flight into exile of large numbers of technical personnel, added to the extensive war damage and lack of proper capital investment, causing serious technical damage to oil facilities and wells. See F. Fesharaki's "Iran's Petroleum Policy: How Does the Oil Industry Function in Revolutionary Iran?", in Haleh Afshar (ed.), Iran, A Revolution in Turmoil (Albany, NY, 1985), pp. 99-1 17, and Javad SalehiEsfahani's "The Oil Sector After the Revolution”, in Saeed Rahnema and Sohrab Behdad (eds), Iran after the Revolution (London, 1996), pp. I50-174. 
Abadan, the course of Iran's history in the following two decades might not have taken a different shape. The population of Abadan had a strong sense of identity, as we shall see later, rooted in a rich and somewhat unique history. Despite the repressive nature of the post-I953 monarchic regime, this ability was manifested in the ability of Abadanis to form the nuclei of autonomous civil institutions, primarily trade unions, as soon as the opportunity presented itself again in the late I970s. The struggle to establish popular and independent institutions of civil society is what Iranian society is striving for even today. Had the oil workers' attempts to defend their independent institutions against cooption not been disrupted by war, not such an unlikely possibility given their strategic role and symbolic weight in the economy, would they have been able to set an example and create a center of gravity inspiring the emergence of similar institutions in other civil and public arenas, subsequently limiting the expanding sphere of the state's hegemony? ${ }^{22}$ These are speculative, but not unfounded questions, meant to point out the range of missed historical possibilities, but also the potentialities that a large company town like Abadan had opened up at a certain point in time.

Fourth, it is likely that the above questions might sound surprising, but if they do it is because the role of "space" and "place" are, by and large, neglected in most social studies. Social movements, relations, and developments do not take place in a void, but are shaped in specific locales and material and physical places. This "space" of social interaction is a product of social relationships, but at the same time it becomes an inseparable organic component of their process of development. Two decades ago the urban population of Iran, for the first time in history, surpassed 50 per cent of the total population. In a coincidence, this symbolic passage to a predominantly urban society happened at the same time that the Iranian Revolution took place. This urbanized society is the product of a contradictory modernity, which has also brought about fundamental changes in the political structures of the country. To better understand and analyze this modernity, and the many forces that had shaped it, one needs also to look at the spaces that this modernity has

22. In the period just before and some time after the Revolution, an interesting shift occurred in the published studies and analyses of the oil industry in Iran. In the period of political upheaval most of the research conducted or published focused on the political role of the oil workers, their organizations and institutions, their various political affiliations, and their relations to existing and competing political forces outside their own group. The work of Ervand Abrahamian, Fred Halliday, Mansoor Moaddell, Assef Bayat, and Farhad Khosrokhavar (although the latter's work is about machining workers in Hamedan) falls into this category. In the period after the Revolution, this focus on social agency gradually disappeared and was replaced with purely economic and functionalist studies of the oil "sector". I do not know of any accounts or analyses of social actors, or of the social and political relations of production within the oil industry, in the period after the early i 980 s. 
created. In other words, we need to ask what types of cities has this urbanized society produced? What types of urbanization? And what forms of citizenships? The modernity that has shaped contemporary Iranian society, like modernity elsewhere, and modernity itself, has not been a uniform and homogeneous process. It has been continuously contested, struggled over, seduced and enticed, forced and resisted by an array of social actors. We can capture the reflection and embodiment of this conflicted modernity, its momentary congealment, in the spaces it has produced. The rest of this essay is an attempt to analyze a specific type of place, the oil company towns of Khuzestan, which happen to have played a significant role in modern urbanization in Iran.

\section{AN ARCHEOLOGY OF COMPANY TOWNS IN IRAN}

From a historical and geographic standpoint, the cities of Abadan and Masjed-Soleyman have been the center and heart of the oil industry in Iran. In many ways the history and experience of their creations is unique and fascinating. In the first place, these were the first thoroughly modern cities in Iran. After the discovery of oil in Masjed-Soleyman by employees of the D'Arcy Concession in 1908, the Anglo-Persian Oil Company (APOC) was incorporated in London. Within four years, the foundations of the cities of Abadan and Masjed-Soleyman had been laid in practically unpopulated regions of Khuzestan. Abadan was a large mudflat island, situated in the estuary of the Tigris-Euphrates-Karun rivers, at the mouth of the Persian Gulf. The island had an estimated population of some 24,000 Bani-Kaab Arab tribesmen, tending sheep and cultivating date palms. This population was dispersed throughout the island in a number of villages. ${ }^{23}$ Similarly, Masjed-Soleyman was a mountainous region in the northeast of the province and the site of seasonal grazing by Bakhtiari nomads.

In a pattern established two centuries earlier by the East India Company in South Asia, the APOC initially leased limited amounts of land in both locations from the Bakhtiari Khans and the Sheikh of Mohammerah (later Khorramshahr). It then began building these cities with the sole purpose of exploration, extraction, transport, refining, storage, and export of oil. Soon, these towns became the focal centers of a new geography that transformed the landscape of Khuzestan and became the site of the concentration of people and labor power employed in this rising global industry. In a short time, the newly founded city of Abadan became the country's fifth largest city, and its population of 225,000 surpassed that of

23. See Ferrier, The History of the British Petroleum Company, vol.r; Ludwig W. Adamec, Historical Gazetteer of Iran, vol. 3, Abadan and Soutbwestern Iran (Graz, 1989); and Mostafa Ansari, "History of Khuzistan, 1878-1925, A Study in Provincial Autonomy and Change" (unpublished Ph.D. thesis, University of Chicago, 1976). 
Shiraz by the end of the Second World War in 1945. For several decades the APOC ranked as the largest employer in the country, and its workforce exceeded the total number of those employed in all the private manufacturing establishments. ${ }^{24}$

The APOC did not invent the company town. At least from the first quarter of the nineteenth century, large capitalist firms in industrial countries - especially in the US, but also in Britain, France, Germany, and even Russia - had been involved in providing residences and some amenities, but also building whole towns in isolated and distant locations to house their labor force. ${ }^{25}$ But this urban form began to undergo significant modifications in the last quarter of the nineteenth century. The historic period of the I870s to I9I4 augured something of a paradigmatic shift in modern history. The political, economic, social, and geographic organization of the capitalist world and its dependencies, its mode of regulation and regime of accumulation underwent significant shifts following a series of interrelated crises and reorganizations and adjustments - setting the stage for the next phase, which dramatically ended with the Second World War. ${ }^{26}$

The Western world and its dominions were entering a new phase of

24. See Ian Seccombe and Richard Lawless, Work Camps and Company Towns: Settlement Patterns and the Gulf Oil Industry (Durham, 1987); R.L. Lawless and I. Seccombe, "The Impact of Oil Industry on Urbanization in the Persian Gulf Region", in H. Amirahmadi and S. el Shakhs (eds), Urban Development in the Muslim World (Rutgers, NJ, 1993), pp. I83-212; Ervand Abrahamian, Iran Between Two Revolutions (Princeton, NJ, 1982); Elwell-Sutton, Persian Oil: A Study in Power Politics.

25. The main sources I have relied on for understanding the comparative aspects of the company-town experience in the West, and how the practice of designing industrial towns took shape, evolved, and was replicated in various locations, are John Garner (ed.), The Company Town (New York, 1992); idem, The Model Company Town; Crawford, Building the Workingman's Paradise; James Allen, The Company Town in the American West (Norman, OK, I966); Manuel Castells, The City and Grassroots (Berkeley, CA, 1983); Sharon Zukin, Landscapes of Power (Berkeley, CA, I99I); Peter Hall, Cities of Tomorrow (London, 1985); Anthony Sutcliffe, The Rise of Modern Urban Planning (New York, I981); and Gwendolyn Wright, Building the Dream (Boston, MA, 1981).

26. See Michel Aglietta, A Theory of Capitalist Regulation (London, 1979), esp. ch. 3 (pp. I $5 \mathrm{I}-2 \mathrm{I} 3)$. This is of course the period that Fordism takes shape. One of the criticisms leveled against the regulationist school is that its view of fundamental shifts in modes of regulation and regimes of accumulation overlooks the basic unity and continuity of capitalist relations of production. Capitalism has displayed the ability to adjust to the successive crises it generates, while remaining fundamentally the same. Furthermore, capitalism's flexibility allows the survival and continuity of various modes and relations of production within the same social formation, as long as they are subjected to the market's hegemony.

This criticism notwithstanding, I think the period beginning with the last quarter of the nineteenth century and ending with the Second World War does mark a fundamental historic watershed. For a brilliant summary see Eric Hobsbawm, The Age of Empire (New York, 1987). In the case of Khuzestan this was a period when the modern nation-state was formed in Iran, marking a definite historic break within national and provincial history. 
progress and complexity. The new era called forth a new level and form of management, discipline, and regulation. This vast and highly integrated "system" needed to be steered with appropriate competence and knowledge, through a course that would ensure both its expansion and survival, as well as the collective interest of both the ruling bourgeoisie and the general population. Ensuring moderation, "equilibrium", and general happiness and universal satisfaction increasingly became the acclaimed goals of the more farsighted segments of the elites (these would also include many leaders of social democratic movements). Responsibility for this social engineering and management fell to an emerging layer of professional elites being produced by the newly reformed universities and professional training institutions. From this period onward, the design and conceptualization of company towns (called industrial towns in England) increasingly fell to these professionals. In two major respects, the results of their efforts differed drastically from the filthy and atrocious industrial towns of the previous era, which had led to continuous misery among workers and numerous revolts. ${ }^{27}$

First, the idea and principles of general "welfare" gained an important place in the design of the company towns of the twentieth century. ${ }^{28}$ In other words, the urban space itself was designed as an instrument that allowed the company not only to house its workers but, through

27. Urban conditions in nineteenth-century industrial cities are the topic of Frederick Engels, The Condition of the Working Class in England (Chicago, IL, 1984), a classic study of Manchester. The fear of threatening urban crowds and the rising movement for reform is brilliantly discussed in the case of London by Gareth Stedman-Jones, Outcast London (New York, 1984). For comparative looks at France, Germany, and the US in this period, see Michelle Perrot (ed.), A History of Private Life, vol. 4, From the Fires of Revolution to the Great War (Cambridge, MA [etc.], I990); Hall, Cities of Tomorrow; Anthony Sutcliffe, Towards the Planned City: Germany, Britain, the United States and France, 1780-1914 (New York, I98I); John Burnett, A Social History of Housing; I8Is-1985, 2nd edn (London, 1986), Wright, Building the Dream; Rabinow, The French Modern; and Benevolo, Origins of Modern Town Planning. Colonial cities at the same period were being used as laboratories of social engineering, and their destiny cannot be seen as separate from metropolitan experience. See Gwendolyn Wright, The Politics of Design in French Colonial Urbanism (Chicago, IL, I99I); Zeynep Çelik, Urban Forms and Colonial Confrontations (Berkeley, CA, 1997); Mariam Dossal, Imperial Designs and Indian Realities (Delhi [etc.], I99I); Anthony King, Colonial Urban Development (London, 1976). Dolores Hayden, The Grand Domestic Revolution (Boston, MA, I981), a brilliant classic, discusses the repercussions of these social changes and the reformist movement on gender relations and on domestic space.

28. See Crawford, Building the Workingman's Paradise; Garner, The Model Company Town; and Wright, Building the Dream. The idea of welfare was by no means limited to company towns, but a cornerstone of the rising social reform movement that affected the types of social responsibility for general welfare that the state was willing to undertake. This led to a massive expansion of the state sector in the major Western nation-states. See Michael Mann, The Sources of Social Power, vol. 2 (Cambridge [etc.], 1993), p. 363, for a sense of the scale of the expansion of the bureaucracy and state functionaries in these five decades. 
"scientific" design and planning by professional specialists ${ }^{29}$ in the field, and through continuous intervention in all aspects of the quotidian life of this labor force and their families, to mold them into skilled and efficient, but also docile, "happy", and modern "human capital".

The second factor that shaped and reformed the design of new company towns was colonialism. As mentioned before, in the period under discussion (I870s-I9I4) colonialism had also entered a new phase where, in addition to the extraction of cheap and abundant raw materials, the cheap labor of the colonies for producing semifinished, or even industrial products, as well as the potential of colonial markets for absorbing massproduced products of the core countries in an increasingly integrated and competitive global market were being considered as key strategies. An important advantage of the colonies was that they allowed technocrats and professional elites to experiment with new models of social engineering and spatial design which, for political reasons, would have been more difficult to implement in the home country. For that reason, the distinction between the "West" and the rest which is routinely referred to in most social and political discourses must be taken with a grain of salt. After all, many of the experimentations in social engineering which paved the way for modernization in both Western and Third-World societies were initially tried out in the colonies, and replicated in the metropolitan countries only after modification and proven results and safety..$^{\circ}$ In other words, the traffic of modernization efforts and experiments was dialectical

The theories and practical experiences of the so-called utopian socialists of the early nineteenth century were an important influence on the reformers of the last years of the nineteenth century. In retrospect, Marx and Engels's critique of these early reformers as "utopian" seems justified. Owen, St Simon, Fourier or their followers had used the vast expanses of North America for creating experimental communities of the future. However, after the end of the American Civil War the conquest of the rest of this continent by immigrants and the eastern states' industrial capital began in earnest, and none of these communities managed to survive the wave that eventually integrated the national space and population. See Carl Guarneri, The Utopian Alternative (Ithaca, NY, I99I). This was even the case for very isolationist religious communities, such as the Mormons, as argued by Donald Worster, Rivers of Empire (New York [etc.], 1985), pp. 74-82. Despite the disappearance of socialist urban experiences, many of their mottoes and practices, such as the ethos of hard and collective work, the primacy of collective over the personal interest, and the collective right to equality and welfare, reappeared in the praxis and discourse of social reformers and especially urban planners of the turn of the century, such as Geodes, Ebenezer Howard, Lyautey, et al. On this connection see especially RogerHenri Guerrand, "Private Spaces", in Perrot, A History of Private Life, pp. 359-450; Hayden, The Grand Domestic Revolution; Robert Fishman, Urban Utopias in the Twentieth Century (Cambridge, MA, I981); Hall, Cities of Tomorrow; and Benevolo, Origins of Modern Town Planning.

29. See footnote io, above.

30. On this point see Çelik, Urban Forms and Colonial Confrontations; Wright, The Politics of Design; and Rabinow, The French Modern. 
and back and forth, though certainly not equal in terms of power and decision-making.

As a result, the transnational corporate power that laid the foundations of the cities of Abadan and Masjed-Soleyman in Khuzestan did not start from scratch, as it had a tremendous wealth of complex and up-to-date historical and practical experience available to it from which it could freely draw. Consequently, the places that the APOC produced in Khuzestan were the results of the latest experimentations of the advanced industrial capitalism of the day in social engineering. ${ }^{3 \mathrm{I}}$ For this reason, instead of sharing similarities with existing Iranian cities, Abadan and MasjedSoleyman, at least in their initial years, belonged to an international category of company towns that advanced industrial capitalism was producing in various locations around the globe. In these cities, or at least in the blueprints their designers had drawn, all unpredictable and spontaneous elements had been eliminated and all details of collective as well as private life in the new urban space had been subjected to conscious planning and design. These designs were drawn at the corporations' headquarters, or in the offices of the professional planners. In other words, in distant places foreign to the locales where the towns were to be constructed, and by planners and designers who rarely had an empathetic knowledge of and insight into the needs and characteristics of these local societies.

In Khuzestan, as in most other similar developments, the locations of the company towns had little to do with favorable environmental considerations, economic factors, or existing local communities, but were rather dictated by the requirements of the oil industry. Masjed-Soleyman

3r. See Institut d'Études et de Recherches Sociales (IERS), “Abadan: Morphologie et Fonction du Tissu Urbain”, Revue Géographique de L'Est, 4 (1964), pp. 337-386; Institut d'Études et de Recherches Sociales (IERS), “Abadan: Tissu Urbain, Attitudes et Valeurs”, Revue Géographique de L'Est, 3/4 (1969), pp. 36I-378. The team that conducted these brilliant and insightful studies comprised Paul Vieille, Abolhassan Banisadr, later the first elected president of the Islamic Republic, who had to escape into exile in 1982, and Zafardokht Ardalan. See also Seccombe and Lawless, Work Camps and Company Towns; Lawless and Seccombe, "The Impact of Oil Industry on Urbanization"; Bamberg, History of the British Petroleum Company, vol. 2; Ferrier, History of the British Petroleum Company, vol. I; and Xavier de Planhol, "Abadan", in Ehsan Yarshater (ed.), Encyclopadia Iranica (Los Angeles, CA, I990). I came across Mark Crinson, "Abadan: Planning and Architecture under the Anglo-Iranian Oil Company", Planning Perspectives, I 2 (1997), pp. 34I-359, only very recently. His research and conclusions parallel many aspects of my own, primarily because he is the first systematically to use the BP archives for his research. On Masjed-Soleyman, see the excellent essay by Kamal Athari, "Masjed Soleyman: Sherkat-Shahri Madaniat-Yafteh", Ettelaat-e Siasi Eqtesadi, 47/48 (I99I), pp. 65-69. There is in addition Danesh Abbasi Shahni, Tarikh-e Masjed-Soleyman (Tehran, I995), a local history of Masjed-Soleyman, substantial parts of which are unacknowledged quotations from works of others, including the article by Kamal Athari. 


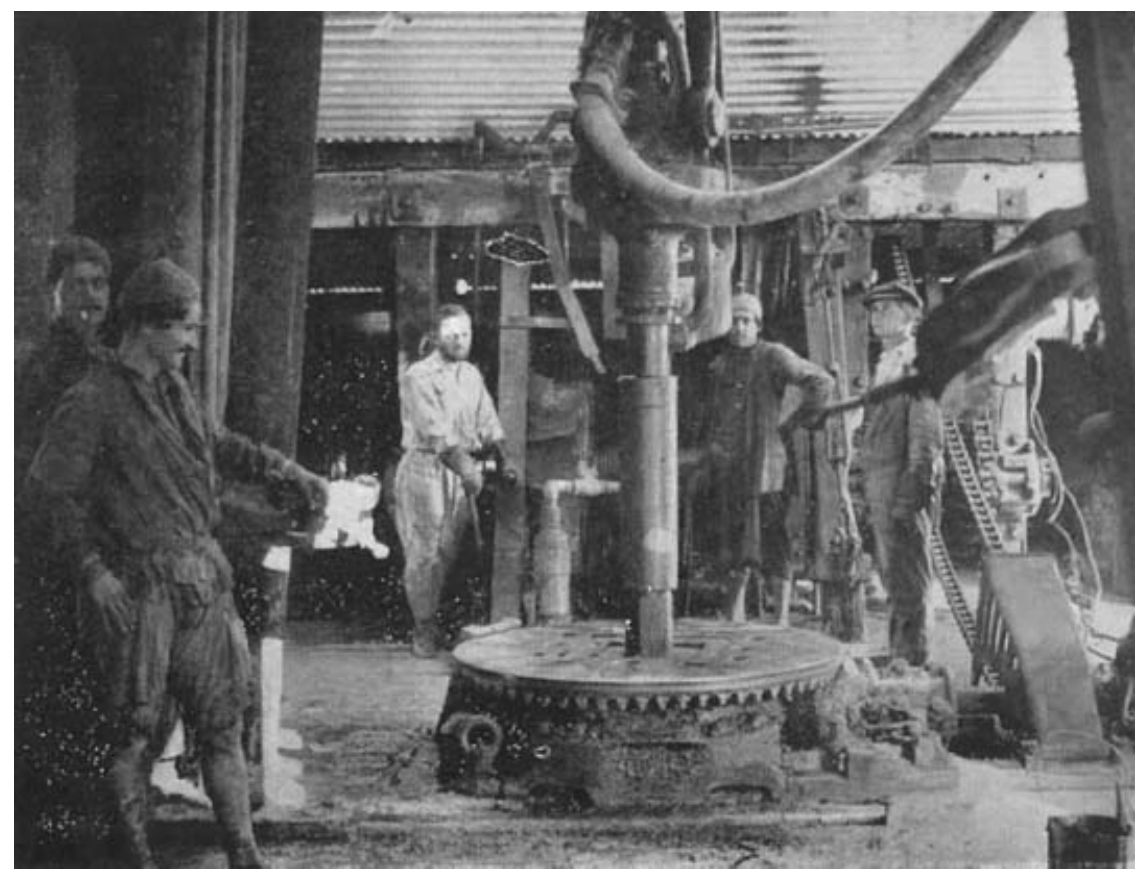

Figure I. Oil drilling in Khuzestan, I920s.

Private collection

was founded around a series of remarkably productive oil wells, in the middle of barren mountains (home to only seasonal Bakhtiari nomads grazing their sheep), and Abadan in a marshy island, populated by tribesmen and palm trees, but which could also provide port access for tankers and cargo ships.

From the onset, Abadan, Masjed-Soleyman, and their smaller sister cities were frontier migrant towns. Their initial populations were mostly men who came from elsewhere, from diverse ethnic and regional backgrounds, in search of jobs and income. In this period Iran was taking its initial fledgling steps towards becoming a modern, centralized, and integrated nation-state. The political atmosphere of the country was unstable and crisis-ridden. The population were predominantly peasants and nomads. Migrant workers in Khuzestan, which at the time was perhaps the most isolated, marginal, and also the wildest region in the country, hired themselves out to an advanced capitalist industrial corporation in exchange for money wages, selling their labor power in order to produce directly for the world market. Their continued settlement there, their occupation, the organization of their material and cultural lives, and the socialization of their households in these new places in a 
sense created a new ethnicity, a new sense of social identity: that of being an Abadani or a Masjed-Soleymani.

This new sense of identity took shape as these towns were rapidly being constructed, with a steady stream of migrants feeding their labor demands. For the new migrants, settling in the radically new and alien places also meant a break from their previous social and spatial settings. As a result, in the two-and-a-half decades between I9I2 and the occupation of Iran during the Second World War, when Abadan and Masjed-Soleyman had already taken their mature shape, their diverse and heterogeneous populations had undergone a generation of being subjected to and shaped by new modes of organizing and ordering their cultural and material lives, profound changes in their collective private and family lifestyles, and the education and molding of their young generations by the newly established educational, technical, and recreational institutions.

The modernity that laid the foundations of these company towns distinguished them, and especially Abadan, from the other historic Iranian cities, even Tehran, the capital. From the Safavid period (in the sixteenth century) to the fall of the Qajar dynasty (I926) the province of Khuzestan had come to be known as "Arabistan", due to the increasing migration of various Arab Bedouin tribes there from the Arabian peninsula and Mesopotamia. ${ }^{32}$ Khuzestan was a frontier territory with virtual autonomy from the central government. In the first two decades of the twentieth century, following the Constitutional Revolution (I906-I9I I), numerous centrifugal forces began to gather momentum, leading the moribund Qajar dynasty on to its last march towards disintegration. This period was the nadir of central power in a decaying and ineffective feudal-tribal state. Sheikh Khaz'al of Mohammerah (later renamed Khorramshahr), who was also the Vâli, or governor, of the province, had become the most powerful provincial governor in the country, paid only nominal allegiance to the Court, and rarely sent to Tehran the taxes and tributes agreed upon. At the time, the plains of Khuzestan were a distant and forbidding territory to the rest of the country, separated from the central plateau by the bulk of the Zagros mountain range, itself populated by unruly and "wild" Kurd, Lur, Bakhtiari, Qashqai, and Kuhgalu tribesmen. Traveling the 750 kilometers between Tehran and Dezful, the province's northernmost and largest city at the time, routinely took several weeks, and it was often safer to travel through Ottoman territory (Tehran-Kermanshah-Bagh-

32. On Khuzestan in this period, see Ahmad Kasravi, Tarikh-e Pansad-Saleh Khuzestan (Tehran, 1934); Ahmad Kasravi, Zendegani-ye Man (Tehran, 1946); Ansari, "History of Khuzistan"; Adamec, Historical Gazetteer of Iran; Arnold Wilson, Southwest Persia: A Political Officer's Diary, 1907-I4 (London, I94I); and Sir Henry Layard, Early Adventures in Persia, Susiana, and Babylon (London, 1971; first publ. I 894). 
dad-Basrah), or sometimes through Russia and the sea route via the Suez Canal (Tehran-Anzali-Baku-Black Sea-Suez Canal-Persian Gulf-Mohammerah) to reach it!33

For Sheikh Khaz'al, the increasing presence of British merchants and officials in the Persian Gulf and his territory presented an opportunity for gaining protection and greater leverage from the central government. Khaz'al saw the formal agreement between Britain and Sheikh Mubarak al Sabbah, the ruler of Kuwait, which put the latter under Britain's protection against the Ottoman Empire, as an ideal model for his own relations with the APOC and the British government. ${ }^{34}$ Both Khaz'al and the Bakhtiari Khans were seeking similar agreements that would define and protect their autonomy as well as perhaps their eventual independence. Meanwhile, in I908, the D'Arcy Concession discovered its first, phenomenally productive oil well in Masjed-Soleyman, an event that dramatically changed the balance of forces throughout the region. Shortly afterwards, the industrial cities of Abadan and Masjed-Soleyman grew like mushrooms from the hills and mudflats of Khuzestan.

In contradistinction to "ordinary" cities, which tend to come together gradually as diverse cultures and economic activities collect together and complement each other, company towns are primarily founded on a much more singular purpose: to satisfy the unavoidable needs of a labor force (for shelter and reproduction) near locations where productive or natural resources owned and exploited by the Company are situated. Consequently, the role of workers and the labor force in company towns is vital, both as agents of production of surplus value and accumulation as well as the very raison d'être for the construction of a company town in the first place. In Khuzestan, the oil company needed to attract its labor force to the region from the very onset. Skilled personnel and managers came from Europe, semiskilled and security staff from India and the Caucasus, and the unskilled from neighboring regions.

Industrial production demands a constellation of behaviors and disciplines that are not limited to mere familiarity with modern machinery. In the first place, the industrial labor force must become familiar with and incorporate time discipline in its body and soul. As E.P. Thompson

33. For more detailed information about travel time and distances, see Haj Abdolghaffar Najmel Molk, Safarname-ye Khuzestan (Tehran, 1984; first publ. c. I872); Charles Issawi, The Economic History of Iran, I 800-1914 (Chicago, IL, I97I); Kasravi, Zendegani-ye Man; Abrahamian, Iran Between Two Revolutions.

34. See William Strunk, "Britain, Persia, and Shaykh Khaz'al: The Genesis of a Special Relationship", in Roger Olson (ed.), Islamic and Middle Eastern Societies (Brattleborough, VT, 1987), pp. I52-17I; Ansari, "History of Khuzistan"; Wilson, Southwest Persia; George Lenckowski, "Foreign Powers' Intervention in Iran During World War One”, in C. Bosworth and C. Hillenbrandt (eds), Qajar Iran (Edinburgh, I983), pp. 76-92. 
persuasively argued in his classic essay on time discipline, the conception of time in an agrarian and pre-industrial society, as Khuzestan certainly was in that period, is the tempo of nature and agriculture. The rise and setting of the sun, seasons changing, and even fluctuations in climate dictate the tempo of pre-industrial life. On the other hand, capitalist industrial time discipline is imposed by two factors: first, the units of a clock, each of which is equal to the next and remains unaffected by natural fluctuations; second, the increasing commodification of various aspects of social life, as a result of which human activities and needs can be quantified, calculated, and measured by the universal medium of money. ${ }^{35}$

The imposition of this industrial order of work and time discipline were among the very first and most critical tasks of the oil company in Khuzestan. According to Arnold Wilson, the British government's representative in the region at the time, "Food is so cheap that the Oil Company must, paradoxically, pay higher wages to get people to work at all. Men's needs are few and they are 'lazy'. In other words, their standard of living includes a large element of leisure, and who shall blame them?" ${ }^{6} 6$ Machine-driven time discipline is the necessary basis of a complex division of labor and cooperation upon which the modern industrial order has been founded. The other leg of this productive system stands on the hierarchy that distinguishes its various interrelated components from one anothersuch as laborers, supervisors, managers, engineers, white-collar staff, and the unemployed - assigning to each its specific place. The industrial system, coupled with a market economy, is fundamentally a class-based system. Consequently, in the tribal and nonindustrial society of Khuzestan at the time the oil company had to, de facto, forge these class relations and

35. On the critical importance of time discipline and temporal coordination in the modern social life under capitalism, see especially Karl Marx, Capital, vol. I (London, I976), and the seminal essay by E.P. Thompson, "Time, Work Discipline, and Industrial Capitalism”, in his Customs in Common (New York, 1993 (first publ. 1967)), pp. 352-403. Nigel Thrift, Spatial Formations (London [etc.], 1996), pp. I69-212, questions Thompson's main point that modern time discipline is inherently linked to industrialization, without convincingly overturning Thompson's argument about the fundamental modernity of the new time discipline and its links with capitalism. This point is also demonstrated from a non-Marxist perspective by Stephen Kern, The Culture of Time and Space, I880-1918 (Cambridge, MA, I983). Without the establishment of unified and standard units of time, complex, modern, and highly coordinated social life is impossible. Georg Simmel made this brilliant point in his essay on "The Metropolis and Mental Life”, in Philip Kasinitz (ed.), Metropolis: Center and Symbol of our Times (New York, I995 (first publ. I903)), pp. 30-45. Practically all interconnected aspects of modern life, from traffic lights to the simultaneous appearance of all employees at their workplace every day, need to be subjected to the global central hegemony of the Greenwich Mean Time. This does not mean that resistance to the time regime, or competition by alternative time disciplines (the religious time of Muslim rituals, for example), is not exercised.

36. Wilson, Southwest Persia, p. I40. 
identities to replace the only hierarchies that were in place, between Khans, sheikhs, peasants, and white beards. ${ }^{37}$

In order to mold a raw and unskilled labor force into proper "human capital" fit to function in a modern advanced industry, it is necessary to first separate it from its existing social and physical environment, and then to reshape it like clay in the hands of a skilled sculptor, through various mechanisms ranging from training, encouragement, seduction, to imposed new material conditions, disciplining, enforced insecurity, and alienation. ${ }^{38}$ In other words, in a process similar to the formation of any other form of capital, raw and unskilled labor power needs a primary accumulation and investment of capital, followed by continuous circulation, use, and maintenance, and reinvestment. The ironic paradox of the capitalist industrial order is in its need, on the one hand, for a skilled and cheap labor force capable of operating the expensive and complex manufacturing machinery - which requires the coordination and simultaneous collaboration of many - juxtaposed, on the other hand, with the fact that the production and maintenance of this cheap labor force is itself an expensive undertaking, and requires heavy and continuous investments. ${ }^{39}$ Consequently, the company town, from the point of view of the company itself, is like a second factory, built next to the main plant (oil wells and refineries in our specific case here), for the production of the other essential component of the production process, namely labor power. The physical spaces of company towns, as we shall see later, are specifically designed with these goals in mind and, therefore, highly charged symbolically and ideologically.

After the 1857 Indian uprising against the East India Company, the British government took charge of the subcontinent and its colonial rule entered a new phase of direct rule. One of the important instruments of British colonial rule in India was the design, renovation, or outright founding of colonial cities, such as Calcutta, Bombay, Simla, Madras, and

37. Shahni, Tarikh-e Masjed-Soleyman.

38. The close connection between modernity and the transformation not only of material conditions, social imaginaires and discourses, but also of individual bodies and souls is the subject of Foucault's Discipline and Punish.

39. Company towns are tremendously costly affairs to build and maintain. See Crawford, Building the Workingman's Paradise. Information is rarely available on the topic, but Athari, "Masjed Soleyman", pp. 65-66, presents one of the rare balance sheets on the topic. The coppermine company town of Sarcheshmeh in the central province of Kerman was built for 2,500 households, with a total population of $\mathrm{I} 2,000$, at a cost of $\mathrm{I} 60$ billion riyals (in I99I riyals). This figure exceeds the total state development budget for the entire housing sector during the 19891993 Five-Year Plan ( I 5.6 billion riyals), the urban development budget for the same period (IOI billion riyals), and the public mining-sector budget (I 2 I.7 billion riyals). 
New Delhi. ${ }^{\circ}$ At roughly the same period, in the British Isles, urban reforms and experimentations, together with innovative housing provisions, had come to rank among the highest priorities for philanthropists and social reformers, socialist politicians, and farsighted industrialists. Suburbanization, blockhouse buildings, new industrial towns, and halfimplemented visionary schemes, like garden cities, were changing the urban landscape of Britain. Across the Atlantic, American industrialists as well as social engineers (architects, urban planners, social scientists, public health officials, concerned politicians, and other technocrats) were also impressed by the bold and paternalistic design of Pullman, Illinois and other such experiments in top-down sociospatial reforms. Across the Channel from England, after the unsettling experiences of Haussmann's reshaping of Paris in the I 850 s and I860s, followed by the trauma of the Commune in the 1870 s, French social engineers had a more constricted field for implementing their reformist and experimental designs at home. Their most talented and ambitious members were compelled to flock to the colonies to give free rein to their ideas. ${ }^{4 \mathrm{I}}$

By 19I4, innovations in urban design had become an accepted and crucial instrument of urban reform and social engineering in the capitalist world and its dominions. But the APOC, a rather sober and tight-fisted private commercial outfit, partly owned by the Scotsmen of the Burma Oil Company, had little inclination for such ambitious undertakings. What it was interested in, first and foremost, was to ensure and maintain its profit margins. The APOC has often been accused of entertaining colonialist designs, especially after its dispute with the nationalist government of Mossadeq led to its direct confrontation with the government of Iran and the oil nationalization disputes, the embargo imposed on Iran by the government of Britain, and finally the 1953 coup d'état. But the truth of the matter seems to be that the APOC harbored little political appetite, and that it at no point was, wanted to be, nor could be another East India Company. In Khuzestan the APOC had discovered a goose that was generously laying golden eggs for it. The dilemma was to keep the goose going, by preventing it from getting more restless or demanding. The awkward and heavy-handed actions of the APOC during the four decades it maintained a monopoly over the oil resources of Khuzestan should be seen in that light.

40. On New Delhi see King, Colonial Urban Development; Robert Grant Irving, Indian Summer (New Haven, CT, I981); and Thomas Metcalf, An Imperial Vision (Berkeley, CA, 1989). On Bombay see Dossal, Imperial Designs and Indian Realities. Lawrence Vale, Architecture, Power, and National Identity (New Haven, CT, I992), offers an important comparative perspective by showing how the production of planned symbolic space in various capital cities is connected to the self-perception of nation-states and their ruling political elites. 4I. See Çelik, Urban Forms and Colonial Confrontations; Wright, The Politics of Design; and Rabinow, The French Modern. 
Nevertheless, the Company had no choice but to house its workers. The choice of location for the founding of Abadan and Masjed-Soleyman was dictated by the logistics and the technical needs of the industry - meaning the extraction, transport, storage, refining, distribution, and export of oil and its derivatives - and not the social and environmental requirements of the staff and the workforce. These cities were built in isolated and rugged locales, but eventually this geographic isolation itself became an important instrument for separating the workforce from their previous physical and social environments, and for molding and shaping them through mechanisms we shall describe later. ${ }^{42}$ After the initial historical experience of constructing these cities, the practice of isolating company towns from existing centers of population became a common and regular feature of this type of urban design everywhere in Iran.

As mentioned above, the practice of designing industrial and company towns had, by the first quarter of the twentieth century, become an international professional occupation. Urban design specialists had access to and used their colleagues' and predecessors' experiences and theories through university education, specialized journals and publications, multinational conferences, and competitive international projects and commissions. In the initial plans of Abadan and Masjed-Soleyman one can detect the traces of two different, but complementary influences, i.e. industrial urban design in Europe and America, as well as in the colonies. Consequently, from the onset, Khuzestan's company towns were "dual cities", ${ }^{43}$ in the sense that their original geographies were designed so as to divide them into several segregated spaces. To begin with, there were the

42. A classic instance is Worcester, Massachusetts. According to Margaret Crawford, this is the first "modern" (postpaternalist) company town in the US, built by the Norton Company after the fiasco of the Pullman strike. Norton Co. attempted to create a layer of dependable skilled laborers who would consider themselves "middle-class" through home ownership. What Crawford's otherwise excellent account misses is the geographic isolation of the city. Although the third largest city in Massachusetts, and located between Springfield and Boston, Worcester is not directly placed on any major road or highway linking these other major cities. At the time, the relative isolation of this industrial city was a deliberate act on the part of its corporate elites and political leaders. I am grateful to the late Professor Romeo Moruzzi for this information. On Worcester's historical geography and the politics of gender and industrial organization, see Susan Hanson and Geraldine Pratt, Gender, Work, and Space (London [etc.], 1995). Geographic location in isolated population centers is today, as much as before, a key strategic ploy of capitalist corporations in the US. See John Logan and Harvey Molotch, Urban Fortunes: The Political Economy of Place (Berkeley, CA, 1987); and Brian Palmer, Goodyear Invades the Backcountry (New York, 1994).

43. I have taken the expression "dual city" from Abu-Lughod, Urban Apartheid, a classic study of the politics of place in colonial and postcolonial Rabat. Although I think Peter Marcuse's criticism of the concept as too reductive is well taken, I think the particular case of these company towns, under foreign ownership and management, with a population seen as either homogeneously "native" or "European", warrants the use of the term. See Peter Marcuse, "Dual City: A Muddy Metaphor for a Quartered City", International Journal of Urban and Regional Research, I3 (1989), pp. 697-708. 
"formal" and the "informal" cities, the former designed and constructed by the Company and remaining under its maintenance and management, the latter growing side by side with the formal town, and, in spite of the company's desires, designed and constructed by migrants, workers, and dwellers attracted to the new city. The "formal" company town was further subdivided into strictly hierarchic and segregated spaces, while the "informal" city was an amalgam of styles, cultures, and social groups. Over time, this glaring contradiction within and between these spaces - between the formal and informal spaces, the legal and subversive, the ordered and disciplined and the chaotic and lively, rich and poor, modern and hybrid, controlled and repressed, and anarchic and spontaneous - came to define the character of these company towns.

The formal space of Abadan, as I mentioned before, consisted of several segregated neighborhoods, the residents of which were carefully assigned housing according to their job, rank in the company roster, and even race, nationality, and ethnicity. A rigid and inflexible hierarchy defined the neighborhood, street, alley, and specific house of each individual employee according to his rank, work record, skill, and even ethnicity, and assigned a house to his family (the employees all being male). Senior European staff were housed in "Braim", which consisted of large villas and bungalows set on green lawns, surrounded by parks and gardens and lined with English hedges, and built on lots averaging $\mathrm{I}, 000 \mathrm{~m}^{5}$, and 4.5 units per hectare. Workers' neighborhoods, such as Bahmanshir and Bahar, were row houses with high walls and tiny courtyards, built in straight lines and wall to wall, averaging $\mathrm{I} 20 \mathrm{~m}^{5}$, with a density of 26 to 3 I units per hectare. In between these extremes lay the middle- and lower-staff neighborhoods, such as Bawardeh, which were combinations of these two forms in terms of architecture, design, and scale.

The spatial discipline that laid out Abadan's urban design like a chessboard was not as spectacularly successful in subjugating the rugged hills and mountains of Masjed-Soleyman to its rational blueprints. Consequently, the design of Masjed-Soleyman appears to be fragmented and unplanned. Nevertheless, as formal company neighborhoods were laid out in the vicinity of workshops, oil wells, and industrial installations, closer scrutiny will show the same segregationist and segmentationist approach as in Abadan, but in a more spread-out and disconnected pattern. With the passage of time and successive political developments, such as the ongoing haggling between the government of Iran and the Company over the composition of the labor force and the distribution of profits from the operations, the share of Iranian employees began to rise considerably. Gradually, the racial segregation that separated the spaces of routine interaction and daily life between Iranians and the English became less marked, in comparison to the occupational and class distinctions that served as the norms segmenting city spaces. Despite all this, what truly set 
Masjed-Soleyman and Abadan apart was their glaring modernity, which was reflected in their unique architecture and design, but also in most other details of urban space and life. These cities were the sites of the first airports, motor vehicles, cinemas, technical schools, mixed schools (boys and girls, foreign and Iranian), leisure clubs, sports clubs, bus services, mass transport, luxury inns, well-equipped hospitals, etc., in Iran and the region. At the same time, all these amenities were segregated for different social layers and classes, to the extent that Masjed-Soleyman even had separate cemeteries for workers and staff. 44

This system allowed the social position and status of each individual employed by the Company to be public knowledge through his residential address, the means of transportation and the medical facilities he and his family were allowed to use, the country and sports clubs he was allowed to join, and the schools his children could attend. At the same time, because the Company's internal organization was also to a large extent a meritocracy, and as each step up the career ladder translated into greater material privileges and social status, the workers were encouraged both to feel envious and to compete against each other, and to pursue individual and personal rather than collective benefits. ${ }^{45}$ Transforming urban amenities and city spaces into symbolic capital was one of the most effective instruments for controlling the population in these cities. ${ }^{46}$

\section{MODERNIZING THE HOUSEHOLD}

The authoritarian spatial design of company towns both reflected the social relations that prevailed within this industry, as well as reinforcing and reproducing them. The company had to not only house its workers (initially there was no housing available in these barren locales); it also had to adapt this raw labor force to the rigorous and special demands of

44. This pattern has been practiced in both colonial settings as well as in company towns in the West. Boleslaw Domanski, Industrial Control over the Socialist Town (Westport, CT, 1997), shows that this practice is equally applied in "socialist" company towns. On the importance of creating distinctions in modern class society see Pierre Bourdieu, Distinction (Cambridge [etc.], 1984).

45. Obviously, not even all skilled personnel or staff, let alone the tens of thousands of unskilled workers, had access to company housing or services. Housing crisis and shortages of amenities and services long remained a major concern of the company as well as the municipality, as well as a bone of contention between them and between the company and the central government. The rapid and substantial growth of the informal sections of Abadan and Masjed-Soleyman were the result of these shortages, and the only practical solution as far as the company was concerned. Nevertheless, the "ideal type" company house and services, as a realistic and achievable goal, was used as an important motivation to encourage both worker and employee loyalty as well as to stir up competition among employees and workers.

46. See Pierre Bourdieu, Le Sens Pratique (Paris, 1980); Timothy Mitchell, Colonizing Egypt (Berkeley, CA, 1988). 
modern industry. It had to retain them, keep them relatively satisfied, or at least dependent on wage labor, but also and at the same time docile. We can witness the reflection of all these goals in details of the urban design, from the architecture of the houses to the types of material used in their construction, in the different designed and organized spaces of entertainment and leisure, the types of wall surrounding the residences and their heights, the length and width of streets and alleys, the morphology of planned formal neighborhoods, and the types of kitchen and bathroom implemented in individual units, etc.

The French geographer, Xavier de Planhol, has argued that the walled-in terraced houses of the workers were designed to duplicate native architecture and a sense of privacy, rooted in "Islamic values". ${ }^{47}$ There is a striking similarity between this argument and the rationalization of the demolition of the old neighborhoods of Algiers under French colonial rule, at about the same time in the interwar period. $4^{8}$ These neighborhoods were replaced with modern apartment blocks, designed by French architects and urban planners, who also tried to incorporate "native" and "Islamic" values and norms in their constructions. In fact, far from reflecting the domestic architecture of the rural and tribal origins of the migrant laborers, these terraced houses were designed with two apparent purposes in mind: first, to mass produce a great number of cheap and durable houses; and second, to intervene directly in the domestic space of the family and to modernize it. 49 The tiny courtyards and high walls prevented air circulation, especially in the atrociously humid and hot summer months. The widespread use of new or modern construction materials, such as bricks, stones, and metal frames, instead of adobe and wood, were faster, standardized, and cheaper but, unlike traditional materials, they did not have the ability to modify extreme seasonal and climatic fluctuations. As a result, these new houses depended on modern amenities, such as electricity, fans, some form of air conditioning, and heaters (gas and electricity, provided by the company, over time became common features in company housing). The provision of these modern amenities, as well as sewerage, piped water, and medical facilities, helped to usher in new notions of personal hygiene and public health.

47. De Planhol, "Abadan".

48. As Zeynep Çelik shows in the case of Algiers, French architects and planners working towards reorganizing the city's space and providing housing for the population also claimed to respect local architecture and cultural values, especially with regard to private space, while in fact a major unrecognized aspect of their work was to modernize the urban population and to dominate them. See Çelik, Urban Forms and Colonial Confrontations.

49. On the key role of the family under capitalism and in modern society, see Jacques Donzelot, The Policing of Families (Baltimore, MD, 1979), and David Harvey, Limits to Capital (Chicago, IL, I982). On the key role of regulating family space as a strategy to integrate the family into the market sphere, see Dolores Hayden, Redesigning the American Dream (New York, 1984), idem, The Grand Domestic Revolution, and Perrot, A History of Private Life. 
The monopoly ownership by the company of the means of production, as well as of reproduction, is the main instrument of social control in company towns. In other words, both occupation and the source of income - as well as real estate, housing, and social services - are in the monopoly of the company. The household unit, aside from being the smallest, collective social unit, plays a key role in many societies in shaping the "individual", and in placing him/her within larger networks of social relations. For this reason macro social institutions and powers, such as capital and the state, consistently attempt to penetrate the household, and to shape and regulate it according to their norms and interests. This intervention often requires the imposition of radical change upon existing household organizations, and sometimes even the prevention of the survival of these older forms. The rigidly fixed residential architecture of Abadan and Masjed-Soleyman, enforced by the company that owned the real estate and housing stock, prevented the accommodation of large extended families, the basic unit of social life in the region. Nor did it allow the use of the domestic space for economic and productive activities, through the maintenance of livestock and chicken, the production of meat, dairy, and eggs, and vegetable garden plots. The small, one- or tworoomed houses were not even practical for traditional handcrafts, such as kilim weaving. All these activities, quite widespread in the region to this day, are crucial for making the household into an economic unit, despite their small scale, by providing income and food supplements. They also bestow status and a sense of identity upon the household, and provide it with relative economic autonomy and self-reliance. As importantly, these economic activities also happen to be the realm of the economic agency of children and, especially, women.

Overall, this domestic architecture promoted the nuclear family as its privileged unit, but it also altered gender roles within the household, as well as the other major division of labor between different generations. In this setting the adult male becomes the sole legitimate economic agent, in the sense of his productive activity being socially validated, through the labor market. The workplace is thus separated and set apart from the place of residence, and the result of his economic activity would return to the household in the form of a money wage or salary. The other consequence of this spatial division of labor is that the house becomes the exclusive domain of the wife/woman, but deprived of the economic and productive activities it previously allowed. At the same time, domestic space also becomes a boundary, between the private and the public domains, and thus a physical constraint for women who can no longer easily and routinely cross the porous boundaries of the household space.

This spatial and gender division of labor, the new role assigned and imposed upon women (which in many ways dramatically limited their social roles) and, in short, this "modernization" of the household which so 
characterized life in Abadan and Masjed-Soleyman reflected directly the developments that were taking place in the capitalist West at about the same time. Contrary to the extended household, the "modern" nuclear family, a form imposed by the domestic architecture of company towns, curtailed the number of children and other generations or relatives who could live under the same roof, primarily because of the shortage of space and the design of the house. Ordinarily, the only other generation who could reside in these houses were the children who, instead of participating in collective household productive activities, were sent out of the home to schools (vocational and regular) in order eventually to replace their parents at home, at the workshop, refinery, and oilfield after several years of disciplined training and socialization. ${ }^{\circ}$

This modernization of the family, gender, and women has been a mainstay of "modernity". However, its early imposition from above in Khuzestan's company towns set the stage for its replication in later periods elsewhere in the country, long after the AIOC had relegated its role to the oil consortium and the Iranian state. The anomie and social problems mentioned have remained acute in the newer and smaller company towns of Khuzestan and elsewhere, such as the agro-industrial model villages of Dezful, the sugar-cane plantations of Haft-Tappeh, the steel town of Mobarakeh, the copper-mining town of Sarcheshmeh, the industrialmachinery town of Arak, etc. This is especially the case for women, where geographic isolation and their seclusion in the household is not relieved by the large scale of the urban setting and the diversity of city life, as it was in Abadan and Masjed-Soleyman. ${ }^{51}$ Possibly, discontent in smaller company towns is caused by the smaller scale and the cultural poverty of these towns, whereas what distinguished Abadan and Masjed-Soleyman, as we shall discuss later, was their exponential growth, in spite and against the wishes of the company, and their maturation into large and multifaceted

50. Extended family can include several generations and several brothers. In Khuzestan the historic pattern of domestic space for this type of household has been several rooms built around a central courtyard. This flexible model allows new couples to move into a separate room, or to build a new room - space permitting. The domestic architecture of company towns, built for nuclear families, consists of one or several rooms, all built under the same roof. This lack of spatial flexibility implies that only the parents and children (of limited numbers) can occupy the house. See Kaveh Ehsani and Mohammad Reza Pourparviz, "Revolution and War in Ramhormoz: Evaluation of an Experience", Goft-o-Gu, 25 (1999), pp. 95-I20; and Grace Goodell, Elementary Structures of Political Life (Oxford [etc.], I986).

5I. For the case of the sugar-cane plantation in Haft-Tappeh, see Ministry of Agriculture, Tarhe eskane karkonane vahedha-ye haftgane-ye tarhe tose'e-ye neyshekar va snaye-e janebi (Tehran, 1990). On Dezful's agribusiness towns, see Goodell, Elementary Structures of Political Life. On planned industrial townships in Iran, see Azam Khatam, "Molahezat-e Ejtema-yi dar Makanyabi va Ehdas-e Shahrha-ye San'ati”, Ettelaat Siasi-Eqtesadi, 53/54 (1992), pp. 59-60. Khatam's research is based on fieldwork and interviews with many residents of several company towns in Khuzestan, Arak, and Isfahan. See also J. Varesi, Do negaresh be sakht-e do no-shabr dar shabrba-ye jadid-e Iran (Tehran, 1994). 
cities that did come to produce diverse, autonomous, and cosmopolitan spaces and a vibrant urban culture and life.

\section{PUBLIC SPACE}

The wide boulevards and the grid pattern that characterized the formal space of Abadan distinguished it from other Iranian cities at the time. Khuzestan's historic cities, Dezful and Shushtar, ${ }^{2}$ follow the local physical topography, primarily as the means of water allocation by gravity. They have narrow, winding alleys and culs-de-sac, lined by high brick or adobe walls, intended to defend neighborhoods from wind and dust, extreme fluctuations in climate, and from physical and military attacks and molestation. In these cities an important part of social life and relations flows and is shaped in the public space of streets and bazaars.

The formal public space of company towns differs from this historical model in several important respects. In Abadan, instead of long and narrow winding alleys forming a maze, the front doors of the row houses open on to either short, narrow, and straight alleys that abut on to large streets at both ends, or directly on to large avenues. In this way, each house is set up as distinct from its neighbors, and separated from the neighborhood, the intimate street life, and ultimately from the workers' society. Any collective protest or suspicious gatherings among neighborhood residents can be quickly detected, and each street, alley, and even neighborhood can be easily cordoned off from the others should the need arise.

The assignment of housing by the company, based on occupation and rank (and race, in the early days of British ownership), and the constant displacement of the personnel within the company hierarchy, made the forging and maintenance of lasting spatial solidarities difficult. Because the independent ability to choose one's residence was denied the workers seeking company housing, the formation of autonomous and spontaneous networks of solidarity in space by using common kinship, ethnic background, or geographic origins, were near impossible.

In Abadan, the obsession to use urban space as an instrument of controlling the population can be readily detected in the details of the design of the neighborhood and public spaces of the formal city. Forty years ago, the French sociologist Paul Vieille and his collaborators pointed out some glaring examples of these coercive aspects of the urban design of Abadan in a study that is still one of the best published examples of spatial

52. On the historical morphology of cities on the Iranian Plateau, see Massoud Kheirabadi, Iranian Cities (Austin, TX, I99I); Michael Bonine, Yazd and its Hinterland (Marburg, I980); and Michael Bonine, "Morphogenesis of Iranian Cities", Annals of Association of American Geographers, 69 (1979), pp. 208-224. 
analysis in Iran. ${ }^{53}$ The motives followed in the urban design of Abadan, they argued, were not the conventions of urban planning, nor the price of land and economic calculation, but the separation and distinction of different areas of the city from one another by a central authority. It is selfevident that if different city neighborhoods are constructed adjacent to each other, the provision of common services and infrastructure would be far cheaper due to the economies of scale. In fact, Abadan's neighborhoods were built apart and separated by wide stretches of empty terrain, wide roads, pipelines, administrative and industrial facilities and, of course, the enormous bulk of the refinery itself. This imposed separation prevents easy intermingling and routine pedestrian interaction, as well as potentially dangerous collective congregation between separate city sections.

Roads do not connect different city sections to traffic exchanges. Rather they end in several bottlenecks that allow the surveillance of all communication between different parts of the city. The boundaries of different neighborhoods are marked by guard posts, and there are regular police stations near or at the entrance to workers' neighborhoods. The Abadan refinery was the monopoly owner of all land in the formal company town. It was responsible for organizing different sections of the city, as well as for creating and maintaining the distinctions between its different parts. It was the force responsible for creating the segregated and hierarchic landscape of the city.

In Masjed-Soleyman, the topography and physical setting had to a large extent aided and modified the process of social engineering. Houses and urban facilities were constructed, in a spread-out fashion, around oil wells and industrial facilities. Specific neighborhoods were often called after these facilities - for example Nomre-e Yek (Number I, referring to the first oil well discovered), Nomre-e Chehel (Number 40), Naftak (Little Oil), Naftoun, etc. The distance and area between neighborhoods was connected by narrow, company-built roads, and rugged hills, left barren and undeveloped. Every attempt to build unauthorized hovels and houses was immediately confronted by the company's bulldozers. As in Abadan, official company areas were built separately from one another, and had only one narrow access road in and out. Neighborhoods were designed either in a circular pattern, or as parallel streets that are interconnected by perpendicular streets, but with dead ends on both sides, cutting and isolating the neighborhood from the world beyond, except through the single, easily guarded access road.

Company neighborhoods were segregated according to rank and status, set in separate places with different amenities and characteristics. The

53. See Institut d'Études et de Recherches Sociales (IERS), “Abadan: Morphologie et Fonction du Tissu Urbain”, and Institut d'Études et de Recherches Sociales (IERS), “Abadan: Tissu Urbain, Attitudes et Valeurs". 
senior managers lived in Shah Neshin (Seat of the King), senior staff in Naftak and Talkhab, junior and petty staff in Nomre-e Chehel, Camp Scotch, and Pansion-e Khayyam, and workers in Naftoun, Do Lane (Two Lanes), Seh Lane (Three Lanes), Bibian, etc.

The space for leisure and entertainment in Masjed-Soleyman was, as in Abadan, differentiated according to rank and class. Senior staff and managers had membership to Bashgah-e Markazi (the Central Club), junior staff had the Bashgah-e Iran, and workers Bashgah-e Kargari (Workers' Club), located in Naftoun. Only members and their guests had access to each club. The rest of the city's population, not employed by the oil company, had no right to use company facilities, especially the clubs. All these social clubs had more or less similar facilities, such as a cinema, restaurant, cafeteria, swimming pool, ping-pong, bingo, billiards, etc. The difference was not so much in the range of amenities as the quality and, more important, the prestige conferred by membership of each institution, which played an important role in bestowing symbolic status on individuals and their family. In Masjed-Soleyman, even the company stores and types of "ration" assigned to each member were distinguished by rank and social class. ${ }^{54}$

\section{PRODUCTION OF PLACE AS A CONTESTED PROCESS}

Place is a social construct that both constitutes and is constituted by social relations. The production of place and the interpretation of its meanings are equally contested processes. People and institutions struggle over defining, using, and shaping space and place according to their individual and collective interests. We have been discussing how the APOC built Khuzestan's oil towns and the architectural and design rationale behind it. I have argued that this rationale was both utilitarian and a discursive exercise of power. The company wanted to attract and maintain a labor force that would be at the same time competent, efficient, modern, and submissive. However, there has always been a fragile balance between the power of the company over place, and its own clear lack of autonomy from both global markets, as well as domestic and local dynamics. On closer scrutiny, we can see that the structured coherence of this industrial landscape has always been shaky and open to contestation.

Company towns of the twentieth century, as mentioned before, have been designed by using two contradictory as well as complementary principles: the idea of general welfare and the assimilation of the labor force into the generic values of the "middle class"; and, on the other hand, 
the praxis of colonialism, both internal and external, in the form of a onesided domination over an alien and weaker region and people, for the main purpose of extracting their natural and human resources and abilities. Contrary to the first principle, the aim of colonial social planning is not necessarily to integrate and standardize the subjugated region and people into a larger unit (national, for example), but rather to create and proliferate its internal divisions, differences, and distinctions in order to better control and dominate it.

The presence of both these principles can be detected in Abadan and Masjed-Soleyman. These cities were built in isolated regions, away from any significant centers of population. Their designed physical and cultural space precipitated a break between the new and migrant population and their mostly tribal and rural background and surroundings. Various planned aspects of the city design and organization generated and maintained new norms, principles, and behaviors conforming to the needs of modern industry. In other words, even though the Oil Company was not a "colonial power" per se, nevertheless it made free use of colonial practices and mechanisms, as well as relying on principles of corporate welfare policies. The standard of living, services, level of education and technical training, and the overall urban culture of Masjed-Soleyman and Abadan exceeded the rest of the country for a long period. In Khuzestan the oil company created a wholly new and modern society. However, the lasting legacy of this experiment was embodied not only in the physical structures it put together. Long after the political events of the oil nationalization movement and the I953 coup d'état brought about the end of the AIOC and its total hegemony over the oilfields of Khuzestan, the social imaginary and the collective forces and institutional practices it had produced have continued to exert a significant influence. The cultural, geographic, and institutional legacy of the AIOC influenced not only the industrial proletariat and management but also had a deep and lasting impact on Iran's then and future "social engineers", namely the planners, urban designers, professional elites of various kinds, industrial managers, and technocrats.

Abadan soon witnessed the growth of a spontaneous city, with a "native" architecture, bazaars, "informal" residential and commercial neighborhoods, illegal hovels and shanties, and especially forbidden places housing brothels, drug sellers, and smugglers, who made the most of the city's location on the border. These subversive places grew across from the manicured lawns and hedges of fancy company neighborhoods such as Braim and Bawardeh. Workers' squatter neighborhoods like Abolhassan, Ahmadabad, and Karun were rapidly constructed next to formal company compounds with fancier literary names such as Pirouz, Bahar, and Farahabad. The formal company town's "public" space was confined to clubs, sports fields, stores, and amenities that only employees of the 
company had access to. In contrast, the informal Abadan city - with its anarchic streets and constant urban confusion and hubbub, its colorful stores, streets teeming with pedestrians and people until the small hours of the dawn - presented a lively, adventurous, exciting, untamed, and unsupervised public arena to all citizens, whether employed by the company or not. The two cities confronted each other with striking contrasts: the formal city was affluent, comfortable, ordered, and staid. It was shaped by disciplinary powers of separation, distinction, ranking, and surveillance that kept its residents under constant control. The spontaneous and informal city was a public place, in the more accurate sense of the word. It was open, integrated, public and, at the same time, quite hectic and anarchic. 55

In these "free zones", which did not belong to the refinery and lay outside its control and surveillance, all manner of people inevitably worked, cohabited, and mixed together: villagers and tribesmen, Arab, Lur, Bakhtiari, Turk, Esfahani, men and women, rich and poor, etc. A third of the population of the "Bazaar" neighborhood and some 60 per cent of residents of the notorious Ahmadabad were company employees who were forced to settle in these neighborhoods due to a chronic shortage of company housing. In other words, the company's efforts to mold and create an ideal society, fit to satisfy its needs, was consistently subverted and ran into crisis as a result of the formation of these adjoining, visible, and accessible free zones. As a result of these tensions and the co-presence of alternative places, the tight and controlled cast of the planned company town was continuously broken, making Abadan and Masjed-Soleyman lively, cosmopolitan places with a strong sense of identity and a sophisticated culture. ${ }^{56}$ The point is that no matter how powerful the oil company and its economic resources and organizational means, it could not in the end manage to impose a full hegemony upon the place it had

55. I follow Jane Jacobs's notion of public space here, as collective space owned neither privately, nor by the state. The importance of public space lies in the fact that it "belongs" equally to all citizens, who can use and be present within it simultaneously, regardless of social distinctions of class, race, or gender. Public space can provide the physical arena for the practical experience of a common urban identity, itself the basis of collective citizenship. As such, public space is an integral part of "civil society". See Jane Jacobs, The Death and Life of Great American Cities (New York, 1961).

The public spaces in Khuzestan's company towns cannot be considered as genuinely "public", as they were owned and controlled by the company. If urban life in these towns broke out of the rigid straightjacket of company control, it was due to the formation of autonomous and truly public spaces within the informal sectors of the city. On the subversive power of unincorporated spaces and populations, see the brilliant essay by Frederick Cooper, "Urban Space, Industrial Time, and Wage Labor in Africa", in idem (ed.), Struggle for the City (Thousand Oaks, CA, I983), pp. I-50.

56. Athari, "Masjed Soleyman", p. 67. 
created. Spontaneous civil institutions, informal networks of trade, guild, political, religious, and ethnic activities were always prominent and exceptionally active in Abadan until the Iran-Iraq war destroyed the city.

In Masjed-Soleyman too, an extended and bizarre informal and illicit space grew around the formal company area. The grand buildings and geometrically aligned company structures contrast with squatter settlements that, after nearly a century, have become permanent fixtures of the city. As mentioned earlier, Masjed-Soleyman's topography is odd, as the city is constructed in a rugged mountainous region, around a series of seven hills. To quote Kamal Athari's excellent study of Masjed-Soleyman:

As the Company prevented the construction of housing units adjacent to its own residential areas migrants were forced to build their dwellings where the company bulldozers were unable to reach and destroy. As a result of this the social, class, and economic differences of the city are reflected in and defended by the sheer cliffs, and deep gorges and flood channels. The city is divided into neighborhoods with English names such as "Camp Scotch", "Khayyam Pension", and "Western Hostel", as opposed to [rugged and informal areas with local names such as] "Kalgeh", "Sar Koureh" ["By the Smokestack"], and "Mal Karim", "Mal" being the smallest social unit of the Bakhtiari.57

\section{CONCLUSION}

In their classic study of the impact of French colonial rule on Algeria, Pierre Bourdieu and Abdelmalek Sayad use the terms "acculturation" and "deculturation" to describe the different experiences of displacement among the mountain Berbers compared with the forced resettlement of the Arab population on the plains of Algeria. The argument is that, due in part to the more rugged and inaccessible geography of their settlements, the Berbers maintained a greater degree of autonomy and internal autonomy than the more geographically vulnerable Arab population of the coasts and the plains. Although many cultural and economic tenets of French rule penetrated Berber society, Berber communities nevertheless managed to maintain a sense of internal coherence and ethnic solidarity which allowed them to adapt and even use many of the material benefits accruing from this European encroachment. The Arabs, on the other hand, were more vulnerable and, despite fierce resistance, were turned into an instrument for successive experiments in social engineering, which included the massive destruction of towns and villages, the forced resettlement of whole populations in concentration camps, military zones, and planned housing complexes and neighborhoods. The experience of the Arabs was a brutal, alienating, and profound deculturation compared to the acculturation of the Berbers, who, despite the hardships they had to endure, at the

57. Ibid. 
same time managed to accumulate certain abilities and resist other encroachments. ${ }^{8}$

In Khuzestan, the establishment of company towns and model villages in the agro-industries of Dezful in the I970s, and the semi-forced resettlement of tens of thousands of peasants, which has been the subject of a thorough study by Grace Goodell,59 was a deculturating experience. But it would be difficult to pass the same kind of judgement on Abadan and Masjed-Soleyman, despite the fact that they were the first and by far the most massive such experiments in social engineering. Despite the fact that life in these cities led to undeniable and fundamental changes in the social life and the culture of their population, nevertheless this migration was voluntary in the end, while in the cities themselves, thanks to the diverse and large population and the dynamic urban setting, the possibility of negotiation and enough room for individuals to maneuver was available. Consequently, Abadan and Masjed-Soleyman had, on the one hand, a modern and authoritarian structure and organization, while on the other hand, thanks to the heterogeneity and energy of their population and the forbidding scale the cities had reached despite the company's wishes and attempts, this modernity always remained conditional. The result of these contradictions were cities and urban cultures that were energetic and dynamic, but also eclectic and hybrid.

As mentioned before, Abadan and its citizens played a significant role in the Revolution of 1979 and its victory. Its physical destruction during the Iran-Iraq war, and the forced dispersal of its population, not only eradicated an important city but also severed from the physical space where it had been engendered a unique industrial and urban culture, a mature and advanced urbanity, and a human capital that had been accumulated over seven decades. Today, after a decade of "reconstruction", Abadan is only a shadow of its former self. Its population, which had reached 300,000 on the eve of the Revolution, was only 2 I 3,000 some six years after the war (I994), while the population of the country had almost doubled compared to two decades before. The war severely damaged the refinery, urban infrastructure and facilities, neighborhoods,

58. Pierre Bourdieu and Abdelmalek Sayad, Le Déracinement (Paris, 1964). For example, Berbers managed to maintain their ties to their places of origin, even when working as migrant workers in France. These ties allowed them to create stronger solidarity and support networks in France itself, which gave them a better standard of living, better pay, and more security. Asghar Karimi and Jean Pierre Digard make a similar argument for Bakhtiari nomads in Iran, when the central state was forcefully trying to settle the tribes in the 1930s. See their "Les Baxtyari sous influence Occidental; Acculturation et Déculturation”, in Yann Richard (ed.), Entre L'Iran et L'Occident: Adaptation et assimilation des idées et téchniques occidental en Iran (Paris, 1989), pp. IOS-II6.

59. Goodell, Elementary Structures of Political Life. 
and the palm groves around the city. The process of postwar reconstruction has been running into serious criticism from the residents. ${ }^{60}$ The activities of the refinery and oil industry are still limited and minimal. Many of the workers and staff are not native to the region. Many of the Abadanis who have returned because of their attachment to their city are dissatisfied and await retirement to settle elsewhere. The morphology and fabric of the city has been altered and its population, as in the early years of its founding, contains many rural and tribal people, while the industrial labor market and the economic institutions no longer have their former ability and resources to shape and influence the population, or to employ them. Social problems, especially addiction and smuggling, are rampant, primarily due to economic depression. But the worst problem is that of the young generation of Abadanis who, for a significant part of their lives, have lived and grown up as refugees and migrants elsewhere - in Tehran, Ahvaz, Esfahan, Shiraz, etc. - and find contemporary Abadan both alien and alienating. The cultural continuity and the accumulation of place identity which gave such a unique character to this city was violently severed at one point, and little has been done to revive or save it from oblivion.

Masjed-Soleyman has not been spared a troubled and uncertain fate either. Since oil resources there dwindled in the late I960s and the remaining oil wells were finally shut in $1980-\mathrm{I} 98 \mathrm{I}$, the city has faced chronic decline. The government transferred most of the oil facilities to the army, on the theory that replacing one gargantuan institution with another would prevent the disintegration of the city, as had happened in small oil towns such as Naft-e Sefid and Haftgel. More than half of the 2,600 company housing units were transferred to the army. ${ }^{6 \mathrm{I}}$ But all the signs are that the success of this strategy has been limited, and Masjed-Soleyman has failed to become a military company town. Instead, the city has found a special place in the regional life of the Bakhtiari tribes. In a twist of historical irony, the city that not so long ago was one of the most industrial cities of Iran and the Middle East today limps along mostly thanks to the presence of nomadic tribesmen. The gradual metamorphosis of the city, from a migrant, industrial and class-based space into an ethnic and tribal one, can be easily detected in the dominant dress code on the streets, where the distinctive Bakhtiari tribal cloths predominate, and in the proliferation of spontaneous housing constructions in hitherto forbidden and inaccessible areas. The absence of capital, like blood circulating in veins, can be easily noticed in the dilapidated conditions of the city, especially in the company neighborhoods. Many of the skilled personnel and workers have migrated elsewhere and play an important role in the strategically

60. See Kaveh Ehsani, “Bohran-e Ab, Bohran-e Abadan”, Goft-o-Gu, 27 (2000), pp. I62-172. 6I. Shahni, Tarikh-e Masjed-Soleyman, p. 345. 
important provincial industries, such as sugar cane, the Abadan refinery, ports, steel mills, and oil facilities.

The intellectually influential journal Iran-e Farda, which in its initial issues used to propagate an economy without oil and considered the period 1952-1953 (when Iran's oil was boycotted by Britain during the oil nationalization crisis) as a model of independent and balanced national development, recently dedicated a special issue to Masjed-Soleyman. ${ }^{62}$ The basic theme of this issue was a grim and dire warning about the inevitability of the end of oil production and revenues as resources run out, and the subsequent social dislocations and pathologies that will result if appropriate care is not taken to deal with this eventuality. From this important journal's viewpoint, delinquency, unemployment, addiction, and depression are the main characteristics of an abandoned and oil-less Masjed-Soleyman, and by extension of the Iran of the future. Even in their decline, Khuzestan's oil towns continue to capture the collective national and intellectual imagination in significant ways.

But perhaps the most important change in Masjed-Soleyman has taken place in the local structure of land ownership. In 1956, more than half of city residents were renters and less than one-tenth of the city's housing stock was privately owned. Currently, these ratios have been almost reversed and most city dwellings are owned privately. The turning point on this issue was the exhaustion of the local oil resources, as well as the 1979 Revolution. The collapse of the monarchy led to important changes in property relations and land ownership in all urban and, to a lesser extent, rural areas. ${ }^{63}$ The populist-socialist and the conservativetraditionalist factions of the Islamic regime battled for years over their conflicting notions of property rights, with the former faction favoring widespread confiscation and distribution of rural and urban land among the people, and the latter defending the sanctity of ownership under Islam. True to form, Ayatollah Khomeini played the middle-of-the-road on this sensitive topic. The end result was the confiscation (often arbitrary) of the properties of the "direct associates of the former regime", on the grounds of their being illicit wealth, without affecting general property relations at all, which remained protected under Islamic law. At this level, the

62. "Special Section: The Future Without Oil: Today's Masjed Soleyman [is] Tomorrow's Iran Without Oil", Iran-e Farda, 50 (I999). It seems that both positions adopted by this important political journal (now banned) - about an economy without oil being the ideal solution for correcting the distortions of a rentier state, as well as a fearsome threat and specter of a povertystricken future - are rather exaggerated.

63. Bernard Hourcade and Farhad Khosrokhavar, "L'Habitat révolutionnaire: Téheran 19791981", Hérodote, 3 I (1983), pp. 62-83, and Asef Bayat, Street Politics (Cairo [etc.], I998) are among the most insightful studies of urban change in postrevolution Iran. For a detailed study of the revolution and war-related transformations at a local provincial level in Khuzestan, see Ehsani and Pourparviz, "Revolution and War in Ramhormoz". 
Table I. Population and housing in Masjed-Soleyman

\begin{tabular}{lccc}
\hline Year & Population & $\begin{array}{l}\text { Privately owned residences } \\
\text { (as percentage of total) }\end{array}$ & $\begin{array}{l}\text { Rental residences } \\
\text { (as percentage of total) }\end{array}$ \\
\hline 1956 & 45,000 & 7 & 50 \\
1966 & 65,000 & 7 & 34 \\
1976 & 77,000 & 14 & 43 \\
1986 & 105,000 & 56 & 9 \\
1996 & 132,000 & 61 & 17 \\
\hline
\end{tabular}

Sources: Ministry of Interior, National Census of Population and Housing (Tehran, various years); Athari, "Masjed Soleyman", pp. 65-69; Ministry of Housing and Urbanism, Rahnamaye Jamiyat-e Shabrba-ye Iran, 1335-70 (Tehran, 1989).

redistribution of land became a political process rather than a universal legal one, and therefore remained a limited, coercive, and often arbitrary occurrence, subject to manipulation and abuse. On the other hand, due to the weakness of the new regime, strict zoning laws, which defined public land and areas for cultivation or construction, were overstepped wholesale by a politicized population hungry for land. By 1980, the metropolitan area of Tehran and most other cities had expanded manifold, as hitherto public land was occupied and converted to housing on a massive scale. In rural areas a similar process happened to significant areas of state-owned and public land (nearly a million hectares altogether), which were occupied and expropriated de facto. This appropriation was based on the Islamic stipulation that any barren land "revived" and maintained for at least three years by labor shall become the possession (and not the "property", that final status being the privilege of the Divine) of the laborer/cultivator.

In Masjed-Soleyman, most existing constructed areas were under the monopoly ownership or in the possession of the oil company in 1979. In 1979-I980, when this sudden takeover of the mostly unbuilt and barren areas of the city happened on a wide scale, the landscape of the city radically altered. In Masjed-Soleyman the shifts in ownership ratios were far more striking than in other urban areas (see Table I). The barren spaces and empty areas that under company dominion separated neighborhoods and inhabited places are today filled with densely built hovels and houses, and ad hoc constructions that have transformed the hitherto fragmented and dispersed geography of the city. Masjed-Soleyman has become an interconnected, very "long” and spread-out sprawl! The city's population, which had a very rapid rate of annual growth of 3.7 per cent in the waning years of maximum oil production (1956-1966), witnessed a rapid decline to I.8 per cent in the next decade (1966-1976). But in the following decade, 1976-1986, the years of war and revolution, of the end of oil production and related jobs, years of de facto economic depression and accelerated emigration from the city, the city population's growth rate reached 3.I per 
cent. One of the main causes of this expansion was immigration from adjacent rural and tribal areas. A major motive for this movement of population was the opportunity to squat and permanently occupy urban land.

The struggle for the possession of land and the housing question have always been strong motives in shaping the geography and identity of company towns. But the manner, content, and result of this struggle continuously underwent modification and reformulation at different historical junctures, according to the balance of power between the main actors involved, namely the oil company (whether owned by the British, made up of a consortium of several multinationals and the central state, or nationalized and wholly state owned), the central state, and the resident population. This ongoing struggle meant that the geography of the city, as well as its identity, its culture, and the social and political aspirations and abilities of its component parts were continuously changing and being overhauled.

The importance of Abadan and Masjed-Soleyman in the history of modernization, contemporary urbanization, and modernity in Iran are undeniable, even if history has not been especially kind to these cities and their population. Perhaps there is some truth to the stark warning of the journal Iran-e Farda that today's Masjed-Soleyman offers an image of the whole country's future without oil. But, precisely for the same reason, the story of these cities cannot and should not be limited to the fate and the narrative of oil revenues alone. Instead, the crisis-ridden and troubled history and geography of these company towns must be rescued from oblivion, as every detail of their story holds precious lessons for the society's present dilemmas. 